\title{
Seasonal changes in the abundance and biomass of copepods in the south-western Baltic Sea in 2010 and 2011
}

\author{
Lidia Dzierzbicka-Glowacka ${ }^{\text {Corresp.. }}{ }^{1}$ ， Anna Lemieszek ${ }^{2}$, Marcin Kalarus ${ }^{2}$, Evelina Griniene ${ }^{3}$ \\ 1 Physical Oceanography Department, Ecohydrodynamics Laboratory, Institute of Oceanology of the Polish Academy of Sciences, Sopot, Poland \\ 2 Department of Ecology, Maritime Institute in Gdansk, Gdansk, Poland \\ 3 Marine Research Institute, Klaipeda University, Klaipeda, Lithuania \\ Corresponding Author: Lidia Dzierzbicka-Glowacka \\ Email address: dzierzb@iopan.gda.pl
}

Background. Copepods are the major secondary producers in the World Ocean. They represent an important link between phytoplankton, microzooplankton and higher trophic levels such as fish. They are an important source of food for many fish species but also a significant producer of detritus. In the terms of the role they play in the marine food web, it is important to know how environmental variability affects the population of copepods.

Methods. The study of the zooplankton community in the south-western Baltic Sea conducted during a 24-month survey (from January 2010 to November 2011) resulted in the identification of 24 invertebrate species (10copepods, 7cladocerans, 4rotifers, 1ctenophore, 1larvacean, and 1 amphipod). Data were collected at two stations located in the open sea waters of the Gulf of Gdansk: the Gdansk Deep (P1) $\left(54^{\circ} 50^{\prime} \mathrm{N}, 19^{\circ} 19^{\prime} \mathrm{E}\right.$ ) and in the western, inner part of the Gulf of Gdansk (P2) (54 $\left.32^{\prime} \mathrm{N}, 18^{\circ} 48.2^{\prime} \mathrm{E}\right)$. The vertical hauls were carried out with the use of two kinds of plankton nets with a mesh size of $100 \mu \mathrm{m}$ : a Copenhagen net (in 2010), and a WP-2 net (in 2011).

Results. The paper describes the seasonal changes in the abundance and in the biomass of copepods, taking into account the main Baltic calanoid copepod taxa (Acartia spp., Temora longicornis and Pseudocalanus sp.). They have usually represented the main component of zooplankton. The average number of copepods at the P1 Station during the study period of 2010 was 3913 ind. $^{-3}$ (SD 2572) and their number ranged from 1184 ind. $\mathrm{m}^{-3}$ (in winter) to 6293 ind. $\mathrm{m}^{-3}$ (in spring). One year later, the average count of copepods was higher, at 11723 ind. $\mathrm{m}^{-3}$ (SD 6980) and it ranged from 2351 ind. $\mathrm{m}^{-3}$ (in winter) to 18307 ind. $\mathrm{m}^{-3}$ (in summer). Their average count at P2 Station in 2010 was $29141 \mathrm{ind}^{-3} \mathrm{~m}^{-3}$, ranging from 3330 ind. $\mathrm{m}^{-3}$ (in March) to 67789 ind. $\mathrm{m}^{-3}$ (in May). The average count of copepods in the year 2011 was much lower at 17883 ind. $\mathrm{m}^{-3}$, and it ranged from 1360 ind. $\mathrm{m}^{-3}$ (in April) to 39559 ind. $\mathrm{m}^{-3}$ (in May).

Discussion. The environmental conditions of the pelagic habitat change in terms of both depth and distance from the shore. Although the qualitative (taxonomic) structure of zooplankton is almost identical to that of the coastal waters, the quantitative structure (abundance and biomass) changes quite significantly. The maximum values of zooplankton abundance and biomass were observed in the summer season, both in the Gdansk Deep and in the inner part of the Gulf of Gdansk. Copepods dominated in the composition of zooplankton for almost the entire time of the research duration. Quantitative composition of copepods at the P1 Station differed from the one at P2 Station due to the high abundance of Pseudocalanus sp. which prefers colder, more saline waters. 


\section{Seasonal changes in the abundance and biomass of copepods in the 2 south-western Baltic Sea in 2010 and 2011.}

3 Lidia Dzierzbicka-Glowacka ${ }^{1}$, Anna Lemieszek ${ }^{2}$, Marcin Kalarus $^{2}$, Evelina Griniené ${ }^{3}$

4

5 1Physical Oceanography Department, Eco-hydrodynamics Laboratory, Institute of Oceanology of

6 the Polish Academy of Sciences, Sopot, Poland

$7 \quad{ }^{2}$ Department of Ecology, Maritime Institute in Gdansk, Gdansk, Poland

$8{ }^{3}$ Marine Research Institute, Klaipeda University, Klaipeda, Lithuania

9

10 Corresponding Author:

11 Lidia Dzierzbicka-Glowacka

12 Powstańców Warszawy 55, 81-712 Sopot, Poland, P.O. Box 148

13 Email address: dzierzb@iopan.gda.pl 
26

\section{Abstract}

Background. Copepods are the major secondary producers in the World Ocean. They represent an important link between phytoplankton, microzooplankton and higher trophic levels such as fish. They are an important source of food for many fish species but also a significant producer of detritus. In the terms of the role they play in the marine food web, it is important to know how environmental variability affects the population of copepods.

Methods. The study of the zooplankton community in the south-western Baltic Sea conducted during a 24-month survey (from January 2010 to November 2011) resulted in the identification of 24 invertebrate species (10 copepods, 7 cladocerans, 4 rotifers, 1 ctenophore, 1 larvacean, and 1 amphipod). Data were collected at two stations located in the open sea waters of the Gulf of

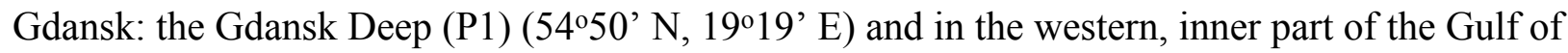

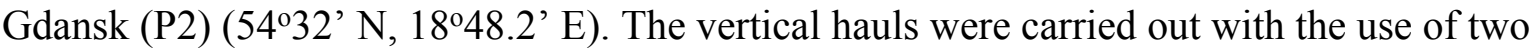
kinds of plankton nets with a mesh size of $100 \mu \mathrm{m}$ : a Copenhagen net (in 2010), and a WP-2 net (in 2011).

Results. The paper describes the seasonal changes in the abundance and in the biomass of copepods, taking into account the main Baltic calanoid copepod taxa (Acartia spp., Temora longicornis and Pseudocalanus sp.). They have usually represented the main component of zooplankton.

The average number of copepods at the P1 Station during the study period of 2010 was 3913 ind. $\mathrm{m}^{-3}$ (SD 2572) and their number ranged from 1184 ind. $\mathrm{m}^{-3}$ (in winter) to 6293 ind. $\mathrm{m}^{-3}$ (in spring). One year later, the average count of copepods was higher, at 11723 ind. $\mathrm{m}^{-3}$ (SD 6980) and it ranged from 2351 ind. $\mathrm{m}^{-3}$ (in winter) to 18307 ind. $\mathrm{m}^{-3}$ (in summer). Their average count at P2 Station in 2010 was 29141 ind. $\mathrm{m}^{-3}$, ranging from 3330 ind. $\mathrm{m}^{-3}$ (in March) to 67789 ind. $\mathrm{m}^{-3}$ (in May). The average count of copepods in the year 2011 was much lower at 17883 ind. $\mathrm{m}^{-3}$, and it ranged from 1360 ind. $\mathrm{m}^{-3}$ (in April) to 39559 ind. $\mathrm{m}^{-3}$ (in May).

Discussion. The environmental conditions of the pelagic habitat change in terms of both depth and distance from the shore. Although the qualitative (taxonomic) structure of zooplankton is almost identical to that of the coastal waters, the quantitative structure (abundance and biomass) changes quite significantly. The maximum values of zooplankton abundance and biomass were observed in the summer season, both in the Gdansk Deep and in the inner part of the Gulf of 
56 Gdansk. Copepods dominated in the composition of zooplankton for almost the entire time of the

57 research duration. Quantitative composition of copepods at the P1 Station differed from the one at P2 Station due to the high abundance of Pseudocalanus sp. which prefers colder, more saline waters.

\section{Main article text}

\section{Introduction}

Zooplankton in the marine pelagic food webs plays an important role in the energy transfer between primary producers (phytoplankton) and higher-level consumers, like pelagic fish (Möllmann, Kornilovs \& Sidrevics, 2000; Dzierzbicka-Glowacka, Bielecka \& Mudrak, 2006; Dzierzbicka-Glowacka at al., 2012; Dzierzbicka-Glowacka, Kalarus \& Żmijewska, 2013). In terms of biomass and production, copepods are the most important taxa of zooplankton in the southern Baltic Sea, e.g. Pseudocalanus sp., Temora longicornis and Acartia spp., while rotifers are mainly represented by Synchaeta spp. and Cladocera, by the dominance of Evadne nordmanni (Dzierzbicka-Glowacka at al., 2015). The species of Pleurobrachia pileus belonging to Ctenophora, the copepod Eurytemora affinis and rotifers Keratella spp. are the least important taxa in the biomass and in the production of zooplankton (Wiktor, 1990; Wiktor \& Żmijewska, 1996; Mudrak \& Żmijewska, 2007). Between the dominant species and those from the bottom of the scale, there are intermediate species living in the Baltic Sea which are characterized by very similar biomass values, e.g. Flitilaria borealis (Appendicularia), the larvae of Polycheata and Bivalvia, cladocerans Bosmina spp. and Podon spp., as well as the copepod Centropages hamatus (Andrulewicz et al., 2008).

The spatial variation in the species composition of mesozooplankton results primarily from the salinity of the Baltic Sea. The lowest number of species (13-20) occurs in the central region of the Baltic Proper and it increases in the marine and freshwater regions. The highest number of species (approx. 28-32) is encountered in the south-western part of the Baltic Proper, which is strongly affected by the North Sea (Andrulewicz et al., 2008).

Copepods are one of the most important links in the food web. They play an important role in the transmission of energy between producers and consumers of higher orders, being food for many pelagic, planktivorous fish (Williams et al., 1994; Froneman et al., 1996). Their 
85 abundance is highly dependent on the physicochemical variables of the environment

86 (Möllmann, Kornilovs \& Sidrevics, 2000; Möller et al., 2015; Karlsson et al., 2018).

87 The main objective of the study was to describe the seasonal changes in the abundance and

88 biomass of the major Baltic copepod species (Acartia spp., Temora longicornis, and

Pseudocalanus sp.) in the Gdansk Basin (the south-western Baltic Sea). The data obtained will be used as a background for future numerical evaluations.

\section{Material and methods}

\section{The Study area}

The Baltic is a shallow, shelf sea from the group of internal (intracontinental) seas. It is the youngest European sea and one of the youngest seas of the Atlantic Ocean. It covers an area of approx. $415000 \mathrm{~km}^{2}$. It is connected with the North Sea through a number of straits: the Danish Straits (Sund, Little Belt and Great Belt), Kattegat, and Skagerrak. The generally accepted division of the Baltic Sea, based on the seabed topography, enables the identification of regions with clearly defined hydrographic parameters (Fonselius, 1969; Omstedt, 1990), i.e. the Gulf of Bothnia, the Bothnian Sea, the Gulf of Finland, the Gulf of Riga, the Baltic Proper (the southern Baltic), the Danish Straits, and Kattegat.

The Baltic waters are characterized by fluctuations in salinity resulting from, i.a., irregular inflows of fresh and saline waters. The inflows of saline waters occur in the western part of the sea through the Danish Straits, which connect the Baltic Sea and the North Sea. This phenomenon contributes to the two-layer structure of the Baltic waters (Matthäus \& Franck, 1992; Fonselius \& Valderrama, 2003; Leppärant \& Myrberg, 2009). The upper layer consists of lighter waters with salinity ranging from 20 PSU in the Kattegat to 2-3 PSU at the northern end of the Gulf of Bothnia and the eastern end of the Gulf of Finland, and with 8 PSU in the Baltic Proper. The surface waters are well-mixed and well-oxygenated, and their temperature differs depending on the season, from $0^{\circ} \mathrm{C}$ to $20^{\circ} \mathrm{C}$. The lower, deep water zone is characterized by the basically constant temperature of $4-6^{\circ} \mathrm{C}$ and higher salinity, ranging from 12 to 20 PSU depending on the region. Stability between these zones is attributed to the halocline, which separates the surface waters from the deep water layer, preventing mixing of the waters, in particular at the open sea area. The Southern Baltic is an area of particular importance to the entire Baltic Sea. Saline waters from the North Sea pass through this region of the Baltic. The direction of the near-bottom flows is affected by the seabed topography. The Słupsk Furrow, 
116 with a maximum depth of $92 \mathrm{~m}$ and with a width of $40 \mathrm{~km}$, is a gateway through which the

117 inflow waters move eastwards from the North Sea. Water inflows from the North Sea raise the

118 salinity of the Baltic waters. The oxygen content and the dynamics of the temperature are

119 determined by the seasons. Although the Gdansk Deep is located off the inflow-water transit

120 axis, it plays an important role in this process (Osiński, 2009).

121 The environment of Gdansk Basin is determined by a varying volume of river runoff; the easy

122 exchange of water with the Baltic Sea, including periodical inflows (infusions) of seawater; and

123 highly variable physicochemical conditions.

124 Seasonal temperature changes occurring in the upper water layer result from seasonal variability

125 in the meteorological elements. They are affected mainly by vertical processes, in particular

126 convection and wind mixing, as well as the Vistula River water inflows into the Gulf of Gdansk,

127 which raise the water temperature in the spring-summer season and lower it in the autumn-winter

128 season (Cyberski, 1995). The water temperature in the layer above the level of $80 \mathrm{~m}$ gradually

129 increases up to the maximum value at the bottom. Due to a lack of contact with the atmosphere,

130 deep waters do not exhibit seasonal changes typical of the upper layer, and their temperatures

131 depend on the temperatures of the inflow waters (Majewski, 1990).

132 The distribution of salinity throughout the year in the surface layer of the Gdansk Basin is

133 affected by the varying volume of river waters reaching the Basin and affecting the anemobaric

134 conditions. Salinity shows a clear seasonal variability in the shallow littoral zone. Differences in

135 the vertical stratification of salinity result from the interactions between the Vistula waters,

136 which reduce the salinity, and the deep waters, which increase the salinity (Majewski, 1990). The

137 salinity of benthic waters (above the level of $80 \mathrm{~m}$ ) also depends on the inflows of saline waters

138 from the North Sea.

\section{Sampling}

140 Plankton samples, which are the basis of in situ studies, were collected in the southern part of the

141 Baltic Sea at the two stations: in the Gdansk Deep (P1) and in the western part of the Gulf of

142 Gdansk (P2).

143 The first series consists of the biological material collected aboard the $r / v$ "Oceania", from the

144 Institute of Oceanology of the Polish Academy of Sciences, during 7 cruises in the area of the

145 Gdansk Deep (5450’ N, 19¹9’E) (Fig. 1, P1 Station), in the period from February 2010 to

146 November 2011. The maximum depth of this site is approx. $100 \mathrm{~m}$. 
147 The vertical hauls were carried out with the use of two plankton nets of $100 \mu \mathrm{m}$ mesh size: a

148 Copenhagen net (in 2010) (Wiktor 1982) and a WP-2 net (in 2011) (HELCOM Manual for

149 Marine Monitoring in the COMBINE Programme of HELCOM, Annex C-7).

150 The plankton net mesh size was selected so as to collect the mesozooplankton together with the

151 younger developmental stages of copepods, which are the main object of the study. A flow meter

152 was placed at $1 / 4$ of the diameter of the net ring in order to determine the amount of water

153 filtered.

154 The material was collected in accordance with the HELCOM guidelines (Manual for Marine

155 Monitoring in the COMBINE Programme of HELCOM, Annex C-7). The vertical net hauls were

156 carried out in the three layers: the bottom - the upper limit of the halocline (with no halocline

157 being present $-75 \mathrm{~m}$ ), the upper limit of the halocline - thermocline (with no thermocline being

158 present $-25 \mathrm{~m}$ ), and the upper limit of the thermocline - the surface. A total number of 21

159 samples was collected, both during the daytime and night-time.

160 Table S1 presents a list of samples collected at P1 Station. The division into seasons used in

161 Table S1 and in the following part of the study was adopted based on the water temperature.

162 The analysed material from the Gdansk Deep was used to determine the composition and

163 seasonal changes in the abundance and biomass in relation to time and space.

164 The second series of the study material consisted of the monthly zooplankton samples collected

165 in the western part of the Gulf of Gdansk (54'32' N, 18 $48.2^{\prime}$ ' E) (Fig. 1, P2 Station) from $11^{\text {th }}$

166 February, 2010 to $29^{\text {th }}$ November, 2011 -from the ship of the Institute of Oceanography of the

167 University of Gdańsk - k/h “Oceanograf 2". The location chosen for collection of the plankton

168 samples was characterized by the depth of $40 \mathrm{~m}$ and was located approx. $18 \mathrm{~km}$ away from the

169 shore. The vertical net hauls were carried out throughout the water column and divided into $10 \mathrm{~m}$

170 thick layers, from the bottom up to the water surface. An exception took place on the $27^{\text {th }}$ of July

171 2011, when the samples were collected from the following layers: 20-0, 30-20 and 40-30 m, due

172 to an equipment failure. In total, 71 samples were collected in this series.

173 Table S2 presents a list of samples collected at P2 Station.

174 The net hauls were carried out only during the day, using (as in the Gdansk Deep in 2011) a WP-

1752 closing net with $100 \mu \mathrm{m}$ mesh size. The flow meter was placed at $1 / 4$ of the net ring in order to

176 determine the amount of water filtered. The collected material was immediately transferred into

177 plastic bottles and treated with 4\% solution of formaldehyde to preserve animals for subsequent 
178 analysis. A total number of 92 samples was analysed to the lowest possible taxonomic level, the 179 copepodite stages of different copepod taxa were identified, and copepod nauplii were assigned 180 to the taxa.

181 The species abundance represents the sum of all development stages in the entire water column.

182 The data for different vertical layers was calculated as the mean value $\left[\mathrm{m}^{-3}\right]$ from depth-stratum 183 three (P1 Station) or four (P2 Station).

184 The biomass was calculated from the abundance of weight standards after Hernroth (1985).

185 The environmental data at the Gdansk Deep (P1), water temperature and salinity were measured 186 in the whole water column using the CTD-probe. Measurements were performed from the $\mathrm{r} / \mathrm{v}$

187 "Oceania" during seven cruises, prior to the biological material collection.

188 The environmental data on the western, inner part of the Gulf of Gdansk (P2) came from direct 189 measurements made with a portable meter for analysing water parameters, and were carried out 190 on board the $\mathrm{k} / \mathrm{h}$ "Oceanograf-2" (16 cruises), and on board the "Hestia" ( 2 cruises). The 191 measurements were made for each depth-stratum separately.

\section{Results}

\section{Environmental conditions during the study period}

Measurements of the hydrometeorological conditions, taken during the biological material sampling (from January 2010 to November 2011), represent an environmental description within a specific time and space frame (S1 Data). In February 2010 the water temperature at the Gdansk Deep (P1) ranged from $1.8^{\circ} \mathrm{C}$ to $9.1^{\circ} \mathrm{C}$ on the surface, and the upper limit of the thermocline was determined at a depth of approximately $60 \mathrm{~m}$. While in June (the same year), the measured water temperature ranged from $10.7^{\circ} \mathrm{C}$ on the surface to approx. $13^{\circ} \mathrm{C}$ in the deepest measured depth $(60 \mathrm{~m})$.

201 The next year, 2011, in March, the water temperature reached the level of $1.4^{\circ} \mathrm{C}$ at the surface and remained constant up to the depth of approx. $65 \mathrm{~m}$, where the thermocline began, and where, below that depth the temperature level significantly increased, reaching the value of $6.2^{\circ} \mathrm{C}$ at the bottom. In June 2011, the water temperature was measured only to a depth of approx. $50 \mathrm{~m}$. The temperature dropped with the depth increase, from $15.2^{\circ} \mathrm{C}$ at the surface to $6.4^{\circ} \mathrm{C}$ at a depth of $50 \mathrm{~m}$. November 2011 was characterized by a high surface water temperature, at $11.5^{\circ} \mathrm{C}$, which remained relatively constant up to a depth of approx. $40 \mathrm{~m}$ and then rapidly dropped at the 
208 greater depths. Due to strong waves and surface-water cooling, the thermocline was at a depth of 209 approx. 40-50 m. The water temperature at the bottom was $5.2^{\circ} \mathrm{C}$.

210 The salinity of surface waters at P1 Station ranged from 7.5 to 6.9 PSU and gradually increased

211 along the depth gradient, reaching a maximum value of 12.6-10.8 PSU at the bottom. In June

212 2010, the salinity was measured only to a depth of $60 \mathrm{~m}$; it ranged from 7.3 PSU at the surface

213 to 6.2 PSU in the deepest layer. Such a large decline in salinity was probably caused by an

214 inflow of flash flood waves into the Gulf of Gdansk after a disastrous spring inundation in the

215 Vistula drainage basin.

216 The temperature of surface water and salinity measured in 2010 and 2011 at P1 Station (based on

217 the example from June) was significantly different during these two years. The runoff of flood

218 waters in May 2010 disturbed the thermohaline system in the Gdansk Deep, which was reflected

219 in the warmer layer of less saline water.

220 The water temperature at P2 Station in the western part of the Gulf of Gdansk was slightly higher

221 for 2010 when compared to 2011.

222 From January to March, the surface-water temperature (approx. $1^{\circ} \mathrm{C}$ ) was lower than the

223 temperature at the bottom. It was gradually increasing from April and was higher at the surface

224 than at the bottom. However, the differences throughout the entire water column were less than

$2251^{\circ} \mathrm{C}$. From July to October, the differences in water temperature became more apparent: in 2010

226 it ranged from 3.4 to $14.1^{\circ} \mathrm{C}$, and in 2011 from 0.2 to $7.0^{\circ} \mathrm{C}$. In November a constant temperature

227 level was observed throughout the water column, at an average of $8.6^{\circ} \mathrm{C}$ in 2010 and $7.3^{\circ} \mathrm{C}$ in

228 2011. The warmest month in both 2010 and 2011 was August $\left(19.4^{\circ} \mathrm{C}\right.$ and $\left.18^{\circ} \mathrm{C}\right)$, whereas the

229 coldest were January and March (ranging from 1 to $2.1^{\circ} \mathrm{C}$ ).

230 The salinity at P2 Station (depth of $40 \mathrm{~m}$ ) varied to a small extent, both during the year and

231 throughout the water column. The mean values of water salinity in the western part of the Gulf of

232 Gdansk ranged from 6.7 PSU (in July 2010) to 7.4 PSU (in October 2011). The lowest salinity

233 level was recorded in July 2010 (6.4 PSU), which probably resulted from the inflow of the

234 Vistula flood waters.

235 Taxonomic composition of zooplankton

236 According to our environmental studies conducted in 2010/2011, a total number of 24 taxa were

237 identified, including10 Copepoda, 4 Rotifera, and 7 Cladocera, as well as juveniles of

238 unidentified Ctenophora, larvacean Fritillaria borealis, and a few specimens of the amphipod 
239 Hyperia galba. In addition, larvae of the benthic fauna were identified as ones belonging to

240 Polychaeta, Bivalvia, Gastropoda and Cirripedia. They were not identified to the species level,

241 but generally defined as meroplankton. Ichthyoplankton was not analysed in detail either. The

242 research showed that the taxonomic composition of the holoplankton in the Gulf of Gdansk was

243 similar to that observed in this region for many years. The exceptions are two invasive species of

244 Cladocera, which occurred in the summer of 2010 in the shallow part of the Gulf of Gdansk -

245 Cercopagis pengoi and Evadne anonyx.

246 Copepoda abundance

247 The open sea waters of the Gulf of Gdansk (Gdansk Deep) - P1

248 Copepods were usually the main component of zooplankton, in both abundance and biomass (S2 249 Data).

250 Due to limited possibilities for the monthly collections of biological material needed for the 251 analysis, data which were collected for selected seasons were interpreted as the average of the 252 entire water column, and different developmental stages were summarized for each species.

253 Nevertheless, they provide a general picture of the situation prevailing at a given time in the 254 pelagic zone.

255 The average number of copepods during the study period of 2010 was 3913 ind. $\mathrm{m}^{-3}$ (SD 2572)

256 and their number ranged from 1184 ind. $\mathrm{m}^{-3}$ (in winter) to 6293 ind. $\mathrm{m}^{-3}$ (in spring). One year

257 later, the average count of copepods was higher at 11723 ind. $\mathrm{m}^{-3}$ (SD 6980), and it ranged from 2582351 ind. $\mathrm{m}^{-3}$ (in winter) to 18307 ind. $\mathrm{m}^{-3}$ (in summer) (Fig. 2) (S2 Data).

259 The maximum number of copepods in spring 2010 in the surface layer (25-0 m) was 12545 ind.

$260 \mathrm{~m}^{-3}$, while in spring 2011 the count of copepods in the same layer was 2.5 times higher. In the

261 other months, the highest values of the copepods count were also recorded in the layer between

262 the upper limit of the thermocline and the surface (S2 Data).

263 The Pseudocalanus sp. had a higher relative proportion at P1 Station than at P2 Station (Fig. 3,

264 Fig. 4, and Fig. 5). This species was the main component of copepods in the winter-spring season 265 of 2010 (approx. 50\%), while it was replaced by Acartia spp. (40.26\%) and Temora longicornis

266 (33.31\%) in summer. During this period, Centropages hamatus accounted for several percent of

267 the copepods, while Eurytemora sp. was insignificant.

268 In 2011, the situation was similar, as Pseudocalanus sp. was the main component of copepods

269 abundance in the winter-spring season (over 50\%), while in the summer-autumn season its 
270 contribution dropped and was similar to that of Temora longicornis - $40 \%$ in summer and $35 \%$

271 in autumn. The percentage of the genus Acartia in the described seasons ranged from 10 to $30 \%$.

272 The presence of Centropages hamatus in this region ranged from a few to several percent, while

273 the count of Eurytemora sp. (similarly to the previous year) was insignificant (Fig. 3).

274 The coastal, inner waters of the Gulf of Gdansk - P2

275 Copepods usually represented the main component of zooplankton. Their average count in 2010

276 was 29141 ind. $\mathrm{m}^{-3}$ (SD 23315), and it ranged from 3330 ind. $\mathrm{m}^{-3}$ (in March) to 67789 ind. $\mathrm{m}^{-3}$

277 (in May). The average count of copepods in 2011 was much lower at 17883 ind. m (SD

278 11407), and it ranged from 1360 ind. $\mathrm{m}^{-3}$ (in April) to 39558 ind. $\mathrm{m}^{-3}$ (in May) (Fig.4) (S3 Data).

279 The maximum count of copepods in May 2010 was determined in the 10-0 m layer, at 161150

280 ind. $\mathrm{m}^{-3}$, while in September 2011, the copepods abundance in the same layer was less than half

281 of that (70 314 ind. $\left.\mathrm{m}^{-3}\right)$ (S5 Data).

282 The analysis of seasonal changes in 2010 revealed two peaks in Copepoda abundance: the first in

283 May and the second in September, with an abundance of 67789 ind. $\mathrm{m}^{-3}$ and 57822 ind. $\mathrm{m}^{-3}$,

284 respectively. In 2011, there was a large peak of abundance in September (39 559 ind. $\mathrm{m}^{-3}$ ) (Fig.

285 6).

286 It appears that the distribution of copepods in the water column is determined by the preferences

287 of a species dominant at a given time and its developmental stage.

288 In March and June 2010, the largest number of copepods was observed in the layer of 30-20 m,

289 while in April - in the 20-10 m layer. During the rest of the year, copepods occurred mainly in

290 the surface layer (10-0 m) (Fig. S1). In 2011, the situation was slightly different. In the early

291 spring and autumn, the largest numbers of copepods were observed in the layer of up to $20 \mathrm{~m}$,

292 whereas in summer, they definitely preferred deeper waters (Fig. S2) (S5 Data).

293 In 2010, the genus Acartia was the main component of copepods in the period from March to

294 September, -ranging from 26.23 to 89.38\%, while in October and November it was at the level of $29532 \%$ (Fig. 4) (S3 Data).

296 Temora longicornis was the second most abundant Copepoda species - from 6.85\% (in July) to

297 44.90\% (in November). In October and November, Temora longicornis dominated and in May

298 its abundance was only slightly lower compared to Acartia spp. 
299 The contribution of Pseudocalanus sp. was also relatively significant and ranged from $21.16 \%$ in

300 March to $29.16 \%$ in April. During the rest of the year, it ranged from only 0.07 (in June) to $3016.43 \%$ (in November).

302 The abundance of Centropages hamatus, similarly to Pseudocalanus sp., was higher in the

303 spring and in the autumn and ranged from 11.38\% in March to $16-17 \%$ in October and

304 November.

305 On the other hand, the contribution of Eurytemora sp. did not exceed 1\% throughout the study

306 period, except for October 2010 when it reached approx. 7\%.

307 In 2011, the genus Acartia accounted for the largest contribution in the abundance of copepods

308 (except for May and June), ranging from 15.81\% (in May) to 85.25\% (in August) (Fig. 5) (S3

309 Data).

310 Temora longicornis was the dominant species among copepods in May (77.19\%) and June

311 (58.42\%). Its contribution in July, October and November was approximately 30\%, and in the

312 other months just several percent.

313 Similarly to the previous year, Pseudocalanus sp. was the most abundant Copepoda species in 314 April (23.45\%), while in the other months it accounted for up to $7 \%$.

315 Centropages hamatus was a significant component of copepods in October (15.16\%) and

316 November (16.33\%), the same as in the autumn of 2010. Its contribution was insignificant for

317 most of the year, ranging from 0.65 (in May) to 5.34\% (in September).

318 In 2011, Eurytemora sp. was rare, only accounting for up to 1.63\% (July) of the total count of 319 copepods.

320 Copepoda biomass

321 The open sea waters of the Gulf of Gdansk (Gdansk Deep) - P1

322 The average biomass of copepods in the zooplankton in 2010 at P1 Station was about 116.68

$323 \mathrm{mg} \mathrm{m}^{-3}$ (SD 37.49) and it ranged from $92.19 \mathrm{mg} \mathrm{m}^{-3}$ (in summer) to $159.84 \mathrm{mg} \mathrm{m}^{-3}$ (in spring),

324 while in 2011 the average value was $321.26 \mathrm{mg} \mathrm{m}^{-3}$ (SD 247.418), and it ranged from 103.67

$325 \mathrm{mg} \mathrm{m}^{-3}$ (in winter) to $676.20 \mathrm{mg} \mathrm{m}^{-3}$ (in summer) (Fig. 7) (S4 Data).

326 The maximum biomass of copepods in spring 2010 was recorded in the surface layer (up to a

327 depth of $25 \mathrm{~m}$ ), at $83.59 \mathrm{mg} \mathrm{m}^{-3}$, and in summer 2011 in the intermediate layer (from the upper

328 limit of the halocline to the upper limit of the thermocline, i.e. $70-25 \mathrm{~m}$ ), at $467.07 \mathrm{mg} \mathrm{m}^{-3}$ (Data 329 S4). 
330 Considering the contribution of individual Copepoda taxa in the zooplankton biomass at P1

331 Station, one can observe a clear dominance of Psedocalanus sp., which accounted for about 50\%

332 of the total biomass of copepods in the winter-spring season of 2010, while in summer 2010 its

333 abundance dropped in favour of Temora longicornis and Acartia spp. (approx. 40\%). The

334 abundance of Centropages hamatus also increased in the spring season up to $23.64 \%$.

335 In the winter-spring season of 2011, Psedocalanus sp. represented approximately $60 \%$ of the

336 Copepoda biomass, while in summer its contribution dropped to $22.88 \%$ and again increased to

$33747.97 \%$ in autumn. Temora longicornis (65.05\%) was the main component of the Copepoda

338 biomass in summer. The contribution of other species was negligible: Acartia spp. from 8.80 to

339 13.33\% and Centropages hamatus from 3.22 to 10.24\% (Fig. 8) (S4 Data).

340 The coastal, inner waters of the Gulf of Gdansk - P2

341 The average biomass of copepods at station P2 in 2010 was $151.46 \mathrm{mg} \mathrm{m}^{-3}$ (SD 115) and it

342 ranged from $33.87 \mathrm{mg} \mathrm{m}^{-3}$ (in March) to $390.12 \mathrm{mg} \mathrm{m}^{-3}$ (in May). In 2011, the average Copepoda

343 biomass was $95.47 \mathrm{mg} \mathrm{m}^{-3}$ (SD 52) and it ranged from $12.40 \mathrm{mg} \mathrm{m}^{-3}$ (in April) to $164.82 \mathrm{mg} \mathrm{m}^{-}$

344 (in September) (Fig. 9) (S3 Data).

345 The maximum biomass of copepods, in May 2010, was recorded in the 10-0 m layer, at 692.12

$346 \mathrm{mg} \mathrm{m}^{-3}$, and at $403.98 \mathrm{mg} \mathrm{m}^{-3}$ in September 2011.

347 When looking into the seasonal changes in the Copepoda biomass in 2010, it appears that a

348 significant peak occurred in May, at $390.12 \mathrm{mg} \mathrm{m}^{-3}$, and that two smaller peaks occurred both in

349 September $\left(186.73 \mathrm{mg} \mathrm{m}^{-3}\right)$ and November (114.36 $\left.\mathrm{mg} \mathrm{m}^{-3}\right)$. In 2011, biomass levelled from

350 June to September, reaching its maximum in September (164.82 $\mathrm{mg} \mathrm{m}^{-3}$ ) (Fig. 9).

351 In March and June 2010, the largest number of copepods was observed in the 30-20 m layer,

352 while in April 2010 it was in the 20-10 m layer. In the other months, the highest values of

353 biomass were determined in the surface layer (10-0 m) (Fig. S3) (S5 Data).

354 In 2011, the biomass values had a similar pattern, except for January and October when the

355 values were slightly higher at the bottom (40-30 m) (Fig. S4) (S5 Data).

356 The species from the genus Acartia spp. dominated in the biomass of copepods at P2 Station for

357 the most of the 2010 season. Their contribution ranged from $18.92 \%$ in November to $89.38 \%$ in

358 September. In March, April and November, they were replaced by Temora longicornis. In

359 October, the biomass of both taxa was at a similar level, approx. $37 \%$. 
360 Temora longicornis was a subdominant in the biomass of copepods. Its contribution ranged from

$3619.65 \%$ (in September) to $55.69 \%$ (in November).

362 As in the case of abundance, a significant percentage of Pseudocalanus sp. in the biomass of

363 copepods was observed only in March (19.63\%) and April (15\%), while in the remaining months

364 it ranged from only $0.10 \%$ (July) to $7.04 \%$ (November).

365 Centropages hamatus was a constant component of the Copepoda biomass, with the highest

366 values recorded in March (20.74\%), April (13.49\%), June (13.55\%), October (16.12\%) and

367 November (17.98\%). The percentage of Eurytemora sp. in the Copepoda biomass was usually up

368 to $1 \%$, except for October, at $7.05 \%$ (Fig. 10) (S3 Data).

369 In 2011, the genus Acartia represented a significant component of the copepods biomass with

370 the contribution ranging from $12.87 \%$ (in May) to $88.16 \%$ (in August).

371 Temora longicornis, being an important and constant component in the biomass of copepods,

372 was observed from April to June, and then in November, ranging from $8.05 \%$ (in August) to

$37379.87 \%$ (in May). In January and November, the biomass values of Acartia spp. and Temora

374 longicornis were similar.

375 The maximum biomass of Pseudocalanus sp. was determined in April, at 14.94\%, while for the

376 rest of the year the biomass values were low. In 2011, the crustacean Centropages hamatus was

377 much more important in the biomass of copepods, at 10\% in January, July, October and

378 November, and ranging from $0.89 \%$ in May to $7.23 \%$ in April. Eurytemora sp. were of minor

379 significance in the biomass of Copepoda, the same as in the previous year (Fig. 11) (Data S3).

380 Discussion

381 In the terms of biomass and abundance, Copepoda are the most important zooplankton taxa in

382 the southern Baltic, and they are mainly represented by e.g. Acartia spp., Pseudocalanus sp. and

383 Temora longicornis. Rotifera: Synchaeta spp., Keratella quadrata, and Cladocera: Evadne

384 nordmanni, Eubosmina maritima and Pleopis polyphaemoides, are more important in the coastal

385 regions, while euryhaline freshwater and typically freshwater species (e.g. Eurytemora sp.)

386 occur mainly at the river mouths and are of lesser importance.

387 Copepods represent one of the largest groups of secondary producers in the World Ocean. They

388 are an important link between phytoplankton, microzooplankton and higher trophic levels such

389 as fish (Longhurst, 1981; Longhurst \& Harrison, 1989; Kleppel, Holliday \& Pieper, 1991;

390 Kleppel, 1992; Dzierzbicka-Glowacka et al., 2011). They are an important source of food for 
391 many fish species, but also a significant producer of detritus. One individual organism can

392 produce 200 portions of fecal matter per day, which is an important source of food for

393 detritivores and is very important in both sedimentation and circulation of biogenic substances

394 processes.

395 The study presents an analysis of 92 zooplankton samples from the Gdansk Deep (Gdansk

396 Basin) and from the western part of the Gulf of Gdansk in the terms of composition, abundance

397 and biomass of zooplankton, with particular emphasis on copepods, as well as on the structure

398 of populations of species occurring in large numbers in the southern Baltic, i.e.

399 Pseudocalanus sp., Acartia spp. Temora longicorni, in 2010 and 2011.

400 Changes in the abundance and biomass of zooplankton

401 Taxa occurring in the samples occasionally or in small numbers (Hyperia galba, Oithona similis,

402 Ctenophora, freshwater Cyclopoida, Harpacticoida) were not included in the determination of

403 zooplankton abundance and biomass.

404 The taxonomic structure of zooplankton observed during the research period was quite typical

405 for the southern Baltic (Mudrak and Żmijewska, 2007). The exception was an invasive species of

406 Cladocera, Evadne anonyx, which occurred in the summer of 2010 in the inner Gulf of Gdansk.

407 This was the first, and so far only observation of this species in the Gulf of Gdansk (Bielecka,

408 Mudrak-Cegiołka \& Kalarus, 2007).

409 The average count of zooplankton in the Gdansk Deep (P1 Station) during the conducted studies

410 was 10685 ind. per $\mathrm{m}^{-3}$ (SD 12 027), whereas in 2011 it was 14607 ind. per. $\mathrm{m}^{-3}$ (SD 9565). The

411 highest mean values of abundance in the water column were recorded in the summer seasons of

4122010 and 2011, at 24238 ind. $\mathrm{m}^{-3}$ and 23659 ind. $\mathrm{m}^{-3}$, respectively. The minimum values were

413 observed in the winter-spring season (1283 ind. $\mathrm{m}^{-3}$ and 2807 ind. $\mathrm{m}^{-3}$ ) (Fig. 12) (S2 Data).

414 The average count of zooplankton in the western part of the Gulf of Gdansk (at P2 Station) in

4152010 was 87122 ind. $\mathrm{m}^{-3}$ (SD 104 836), and in 2011 it was 31649 ind. me (SD 20 487). In 2010,

416 the maximum average count of zooplankton in the water column was recorded in July, whereas

417 in 2011 in September it was 282166 ind. $\mathrm{m}^{-3}$ and 56657 ind. $\mathrm{m}^{-3}$, respectively. The minimum

418 values were recorded in March 2010 (3617 ind. $\mathrm{m}^{-3}$ ) and April 2011 (7249 ind. $\mathrm{m}^{-3}$ ) (Fig. 13)

419 (Data S3).

420 The zooplankton at P1 Station varied, depending on the seasons, although not as much as in the

421 shallow regions of the Gulf of Gdansk. In the two-year cycle of the scientific studies, copepods 
422 were the main component of zooplankton, representing from $69 \%$ of the total zooplankton in

423 spring 2011 to $96 \%$ in spring 2010 (except for the summer in 2010, approx. 18\%) (S2 Data).

424 In 2010 and 2011, copepods occurred at P2 Station throughout the study period and for most of

425 the months they were the main component of zooplankton, with the contribution ranging from

426 approx. 67\% (in September) to 92\% (in March) in 2010 and from $47 \%$ (in June) to 93\% (in

427 January) in 2011, except for May (24\%) and July (over 9\%), when rotifers dominated in the

428 zooplankton. In August, the contribution of Copepoda was similar to Cladocera and Rotifera and

429 amounted to approx. 40\%. In 2011, the exceptions were April and July, when pelagic fauna was

430 dominated by meroplankton, mainly veligers of bivalves (S3 Data).

431 Copepods were the main component of the zooplankton biomass at P1 Station for the whole

432 study duration, with the contribution ranging from $55.3 \%$ in summer 2010 to $99.2 \%$ in winter 4332010.

434 The situation was different at P2 Station. In March, April and June, as well as in September,

435 October and November 2010, Copepoda accounted for the main part of the zooplankton biomass, 436 from 67.6\% in October to approx. 94.6\% in March. In May, July and August, as a result of the

437 seasonal zooplankton components occurring during these months (e.g. Cladocera), the proportion

438 of copepods significantly decreased and ranged from 24.2 to $36.7 \%$. In 2011, copepods

439 dominated at P2 Station, and their contribution in the total biomass ranged from 31.7\% (in April)

440 to $96.7 \%$ (in January). In April, juvenile stages of the benthic fauna dominated in the

441 zooplankton biomass at $64.35 \%$, while in the following months their contribution dropped to

$4427.03 \%$, and then increased again in July, to $34.95 \%$ (S3 Data).

443 Changes in the abundance and biomass of Copepoda

444 The coastal region of the Gulf of Gdansk is wide open towards the Gdansk Deep, which is part

445 of the Gdansk Basin, the southernmost part of the Gotland Basin, which is the largest and the 446 deepest basin of the Baltic Sea.

447 The vertical profile of waters in the Gulf of Gdansk can be divided into two layers. The surface

448 layer in the coastal area reaches the bottom. In the deeper part, it is separated from the lower

449 layer by the intermediate waters, up to $60-80 \mathrm{~m}$ in depth. The surface layer is subject to seasonal

450 changes in temperature, caused by meteorological factors, convection, wind mixing and the

451 impact of the Vistula River water, which causes warming in spring and summer and cooling in

452 autumn and winter seasons. The impact of the Vistula River varies during the year: in spring and 
453 summer seasons it covers almost the entire gulf while in November it is limited to estuaries.

454 This is due to the force and the direction of winds. There is a difference in the vertical

455 distribution between the coastal and the deep-sea regions. The coastal areas have higher

456 temperatures in summer compared to the surrounding waters, while in winter they are cooler.

457 The annual report shows that the salinity in the Gulf of Gdansk is lower in winter than in

458 summer. A key factor affecting the salinity of the surface waters are fresh waters from the

459 Vistula River.

460 The environmental conditions of the pelagic habitat change with both depth and distance from

461 the shore. Although the qualitative (taxonomic) structure of zooplankton is almost identical with

462 that of the coastal waters, the quantitative structure (abundance and biomass) changes quite

463 significantly. The maximum values of zooplankton abundance and biomass were observed in the

464 summer season, both in the Gdansk Deep and in the inner part of the Gulf of Gdansk. Copepods

465 dominated in the composition of zooplankton for almost the entire duration of the research.

466 Quantitative composition of copepods at P1 Station differed from that at P2 Station due to the

467 high abundance of Pseudocalanus sp., which prefers colder, more saline waters. Other species

468 typical for colder and more saline waters were Acartia longiremis, which was also more

469 abundant at lower water levels, while $A$. bifilosa and $A$. tonsa were more common in the surface

470 waters and in the coastal area. In general, Acartia species distribution is strongly connected with

471 salinity, and with decreasing salinity from the open part of the Baltic Sea towards both the Gulf

472 of Finland and the Gulf of Bothnia, the proportion of Acartia decreases, while Eurytemora

473 increases (Simm and Ojaveer, 2000). In the gulf of Riga Acartia bifilosa dominates in winter-

474 spring (it composes 58-68 \% of total zooplankton) while Eurytemora becomes the dominant

475 species during summer (Ojaveer, 2017). In the Gulf of Gdansk Eurytemora plays only a minor

476 role and the contribution to the total zooplankton biomass is less than $10 \%$ over the whole year.

477 In the open part of the Gulf of Gdansk the concentration of Pseudocalanus sp. and

478 T. longicornis was higher compared to the coastal station (Dzierzbicka-Głowacka at el., 2013;

479 2015). In agreement with another study (Ackefors, 1981) Pseudocalanus tend to dominate in

480 offshore areas of the Baltic Sea, rather than in the coastal zones, and it is rarely present above

481 the thermocline during the warm summer period. In the offshore deep areas, this genus can

482 constitute $70-100 \%$ of all copepods in the water column (Ackefors and Hernroth, 1972). 
483 In both 2010 and 2011, Pseudocalanus sp. was the main component of copepod biomass and

484 abundance at the P1 Station in the winter-spring season (approx. 50\% and 60\% of the abundance

485 and biomass, respectively), and in the summer-autumn season its contribution dropped and was

486 similar to that of Temora longicornis: approx. $40 \%$ in summer and $35 \%$ in autumn. The

487 percentage of the genus Acartia in these seasons ranged from $10 \%$ to $30 \%$.

488 The analysis of the variation in the Copepoda taxonomic structure in the inner part of the Gulf of

489 Gdansk at P2 Station indicates that Acartia spp. dominated in the copepods composition. Its

490 contribution in 2010 ranged from 26\% (in March) to 89\% (in September), and in 2011 it ranged

491 from 16\% (in May) to 85\% (in August), while in October and November it was approx. 32\%.

492 Temora longicornis was a sub-dominant species in the terms of abundance and biomass of

493 copepods in the Gulf of Gdansk. Its maximum contribution in the total abundance at P2 Station

494 was approx. 45\% (in November 2010), 77\% (in May 2011) and approx. 56\% (in November

495 2010) and 80\% (in May 2011) in the biomass.

496 Abundance, comparison with other data

497 Taking into account the two periods - 2006/2007 (Dzierzbicka-Glowacka, Kalarus \&

498 Żmijewska, 2013) and 2010/2011 - the total count of copepods in the Gdansk Basin (at P2

499 Station) was characterized by a significant increase (three- and twofold) in the maximum

500 abundance within the 10-0 m layer in May 2010 (161 150 ind. $\mathrm{m}^{-3}$ ) and within the 20-10 m layer

501 in July 2007 (127 000 ind. $\mathrm{m}^{-3}$ ), as well as in the average value in the water column, at 67790

502 ind. in May 2010 and 83500 ind. in July 2007, - compared to 2006 and 2011. In 2014, in the

503 Lithuanian Baltic Sea, at the coastal stations (B1-B4) and at the open sea stations (B5-B9) (Table

504 1), the average abundance of copepods in the surface layer (36 320 and 21327 ind. $\mathrm{m}^{-3}$ ) was

505 similar to the values from 2011 and 2006 for the Gulf of Gdansk and they were about two and

506 four times lower than in 2011 and 2010, respectively. (Table 1).

507 In general, the maximum contribution (\%) of Acartia spp., Temora longicornis and

508 Pseudocalanus sp. in the abundance of Copepoda at P2 Station in the western part of the Gdansk

509 Gulf was similar in the two periods of 2006/2007 and 2010/2011 (Table 2). The population

510 dynamics of the main Baltic calanoid copepod species in the Gdansk Basin in the two study

511 periods was characterized by an increase in the maximum percentage contribution of Acartia

512 spp. (up to 90\%) and Pseudocalanus sp. (up to 29\%) and by a decline of Temora longicornis (to

$51345 \%$ ) in the abundance of copepods in 2010, and a major growth (up to 77\%) of T. longicornis in 
514 2011, as well as a decline of Acartia spp. and Pseudocalanus sp. in 2011, to the level from the

515 period of 2006/2007. In the other cases, the percentage of individual taxa was at a similar level at 516 all of them, throughout the study period.

517 The taxon Acartia spp. had the highest percentage contribution (approx. 82-90\%) in all the

518 studied years, particularly in the summer season (June-September). Temora longicornis

519 accounted for approx. 45-57\% (i.e. almost half the Acartia abundance) of the total Copepoda

520 abundance in the studied periods (2006/2007 and 2010/2011; except for 2011 - with 77\%), i.e.

521 late spring/summer season (May/June) and autumn season (November) when, soon after or

522 before these periods, Acartia spp. reached the first of its second peak in abundance, respectively.

523 On the other hand, the highest contribution of Pseudocalanus sp., the third most abundant

524 copepod species in the inner part of the Gulf of Gdansk, was observed in the early spring

525 (March/April at approx. 23-29\%), except for in 2006 (in February at 25\%). Pseudocalanus sp. is

526 a typical representative of the winter zooplankton. Outside the winter season, the taxon is present

527 mostly in cooler, deep-water layers in the Gulf of Gdansk (Siudziński, 1977).

528 At P1 Station (The Gdansk Deep) in 2010 and 2011, the maximum contribution (\%) of Acartia 529 spp. (40-33\%) was similar to that of Temora longicornis (33-45\%) and two times lower than at

530 P2 Station. However, Pseudocalanus sp., had the highest percentage contribution (approx. 53-

$53162 \%$ ), particularly in the spring time (April).

532 The percentage contribution which has been observed for this species in the Gulf of Gdansk (P1)

533 was similar to that which has been observed in the Lithuanian Baltic Sea on the open sea stations

534 (B5-B9): for Acartia spp. and Temora longicornis for the average values (in ( )), in turn for

535 Pseudocalanus sp. for the maximum value (in [ ]) (Table 2).

\section{Conclusion}

537 The taxonomic composition of the zooplankton in the Gulf of Gdansk appears to be stable. An

538 additional difficulty in comparing the data from different years results mainly from the various

539 sampling methods, especially the mesh size of the sampling nets used. It appears that the high

540 similarity of zooplankton composition between the Gdansk Deep and the more coastal part of the

541 inner Gdansk Gulf confirms that the latter is highly influenced by the open sea waters of the

542 Baltic proper. This makes it different from the other large Baltic gulfs, the Gulfs of Bothnia,

543 Finland and Riga, which differ from the Baltic proper by their biotic and abiotic characteristics

544 and are often categorized as their own autonomous subunits (Ojaveer and Elken 1997). 
545 Thorough knowledge of the species composition, the dominance of particular taxa, density and

546 biomass -- in combination with abiotic - makes it easier to assess changes which take place in

547 the ecosystem. In combination with the simulation models, such knowledge provides

548 hypothetical forecasts for the future, leading to anticipation of positive or negative effects of

549 environmental changes.

550

551

Acknowledgements

552

We express our gratefulness to the anonymous reviewers for their valuable comments on the

553 earlier versions of the manuscript.

554

555

References

556

Ackefors H., Hernroth L. 1972. Djurplankton I Östersjöområdet. Zoologisk Revy, 34:6-31 (in

557 Swedish).

558 Ackefors A. 1981. Biological Oceanography, In Voipio, A. (ed.), The Baltic Sea: 30. Elsevier 559 Scientific Publication Company, Amsterdam, pp. 238-255.

560 Andrulewicz E, Szymelfenig M, Urbański J, Węsławski JM, Węsławski S. 2008. Baltic Sea -

561 it is worth knowing about it. Polish Ecological Club, East Pomeranian District, Poland. ISBN 83562 903702-2-0: 115 (in Polish).

563 Bielecka L, Mudrak-Cegiołka S, Kalarus M. 2014. Evadne anonyx G. O. Sars, 1897 - the first 564 record of this ponto-Caspian cladoceran in the Gulf of Gdańsk (Baltic Sea). Oceanologia 565 56(1):141-150.

566 Cyberski J. 1995. Contemporary and forecast changes in the water balance and its role in 567 shaping the salinity of the Baltic Sea. Dissertations and monographs 206, University of Gdansk 568 Publishing House, Gdańsk, Poland. (in Polish)

569 Dzierzbicka-Glowacka L, Bielecka L, Mudrak S. 2006. Seasonal dynamics of Pseudocalanus 570 minutus elongatus and Acartia spp. in the southern Baltic Sea (Gdansk Deep) - numerical

571 simulations. Biogeosciences 3: 635-650.

572 Dzierzbicka-Glowacka L, Żmijewska IM, Mudrak S, Jakacki J, Lemieszek A. 2010.

573 Population modelling of Acartia spp. in a water column ecosystem model for the South-Eastern

574 Baltic Sea. Biogeosciences 7:2247-2259. 
575 Dzierzbicka-Glowacka L, Jakacki J, Janecki M, Nowicki A. 2011. Variability in the

576 distribution of phytoplankton as affected by changes to the main physical parameters in the

577 Baltic Sea. Oceanologia 53(1) Special Issue: SI Pages: 449-470.

578 Dzierzbicka-Glowacka L, Piskozub J, Jakacki J, Mudrak S, Żmijewska M. 2012.

579 Spatiotemporal distribution of copepod populations in the Gulf of Gdansk (southern Baltic Sea).

580 Journal of Oceanography 68(6):887-904 (DOI: 10.1007/s10872-012-0142-8).

581 Dzierzbicka-Glowacka L, Kalarus M, Żmijewska MI. 2013. Inter-annual variability in

582 population dynamics of main mesozooplankton species in the Gulf of Gdansk (southern Baltic

583 Sea): I. Seasonal and spatial distribution. Oceanologia 55(2): 409-434. (DOI:10.5697/oc.55584 2.409).

585 Dzierzbicka-Glowacka L, Kalarus M, Musialik-Koszarowska M, Lemieszek A, Żmijewska

586 MI. 2015. Seasonal variability in the population dynamics of the main mesozooplankton species

587 in the Gulf of Gdańsk (southern Baltic Sea): Production and mortality rates. Oceanologia 57:7858885.

589 Fonselius SH. 1969. Hydrography of the Baltic Deep Basins. III. Fishery Board of Sweden.

590 Series Hydrography. Report 23:1- 97.

591 Fonselius S, Valderrama J. 2003. One hundred years of hydrographic measurements in the

592 Baltic Sea. Journal of Sea Research 49 (4):229-241.

593 Froneman P.W., Pakhamov E.A., Perissinotto R., McQuaid C.D. 1996. Role of

594 microplankton in the diet and daily ration of Antarctic zooplankton species during austral

595 summer. Marine Ecology Progress Series 143:15-23.

596 Hernroth L. 1985. Recommendations on methods for marine biological studies in the Baltic

597 Sea. Baltic Marine Biologists. No 10. Institute of Marine Research. Lysekil.

598 Karlsson K, Puiac S, Winder M. 2018. Life-history responses to changing temperature and 599 salinity of the Baltic Sea copepod Eurytemora affinis. Marine Biology 165(2):30.

600 Kleppel GS, Holliday DV, Pieper RE. 1991. Trophic interactions between copepods and 601 micoplankton: a question about the role of diatoms. Limnology and Oceanography 36:172-178.

602 Kleppel GS. 1992. Environmental regulation of feeding and egg production by Acartia tonsa off 603 southern California. Marine Biology 112:57-65.

604 Leppäranta M, Myrberg K. 2009. Physical oceanography of the Baltic Sea. Springer-Praxis, 605 Heidelberg, Germany. 
606 Longhurst AR. 1981. Analysis of marine ecosystems. Academic Press. Elsevier, London, UK.

607 Longhurst AR, Harrison WG. 1989. The biological pump: profiles of plankton production and 608 consumption in the upper ocean. Progress in Oceanography 22:47-123

609 Majewski A. 1990. Morphometry and hydrography of the catchment. In Majewski A. (ed.) Gulf 610 of Gdansk. Geological Publishing House, Warsaw, Poland (in Polish)

611 Matthäus W, Franck H. 1992. Characteristics of major Baltic inflows-a statistical analysis.

612 Continental Shelf Research12: 1375-1400.

613 Möller KO, Schmidt JO, St.John M, Temming A, Diekmann R, Peters J, Floeter J, Sell AF, 614 Herrmann J-P, Möllmann C. 2015. Effects of climate-induced habitat changes on a key

615 zooplankton species. Journal of Plankton Research 37(3):530-541.

616 Möllmann C, Kornilovs G, Sidrevics L. 2000. Long-term dynamics of main mesozooplankton 617 species in the central Baltic Sea. Journal of Plankton Research 22(11):2015-2038.

618 Mudrak S, Żmijewska MI. 2007. Spatio-temporal variability of mesozooplankton from the Gulf 619 of Gdańsk (Baltic Sea) in 1999-2000. Oceanological and Hydrobiological Studies 36(2):3-19.

620 Ojaveer E, Elken J. 1997. On regional subunits in the ecosystem of the Baltic Sea, In Ojaveer

621 E. (ed.) Proceedings of the 14th Baltic Marine Biologists Symposium, Estonian Academy 622 Publishers, Tallinn, Estonia, pp. 156-169.

623 Ojaveer E. 2017. Ecosystems and Living Resources of the Baltic Sea: their assessment and 624 magegment. Springer International Publishing AG, Switzerland.

625 Omstedt A. 1990. Modelling the Baltic Sea as thirteen sub-basins with vertical resolution.

626 Tellus Series A: dynamic Meteorology and Oceanography 42(2):286-301.

627 Osiński R. 2008. Simulation of dynamic processes in the Baltic Sea based on ocean-ice coupled 628 model. PhD Thesis, Institute of Oceanology, Polish Academy of Sciences, Sopot, Poland.

629 Simm M, Ojaveer E. 2000. Dynamics of copepods and fish larvae in Pärnu Bay (NE part of the 630 Gulf of Riga) in the spring-summer period. Proceedings of the Estonian Academy of Sciences, 631 Biology and Ecology 49(4): 317-326.

632 Siudziński K. 1977. Zooplankton of Gdańsk Bay. Studies and Materials of the Marine Fisheries 633 Institute, Gdynia, Poland 18A:1-111 (in Polish)

634 Wiktor K. 1982. The influence of sampling methods for results of quality and quantity analyses 635 in the zooplankton of Southern Baltic coastal waters. Zeszyty Naukowe Wydziału BiNoZ 636 Uniwersytetu Gdańskiego, Oceanografia 9:93-109. (in Polish) 
637 Wiktor K. 1990. Biomass and abundance of the zooplankton from the Gulf of Gdańsk.

638 Limnologica. 20:75-79.

639 Wiktor K, Żmijewska M.I. 1996. Zooplankton biomass in the coastal waters of Gdańsk Bay.

640 Studies and Materials of the Oceanography 46, Marine Biology 7, 70-111, KBM PAN (in Polish)

641 Williams R, Conway D.V.P., Hunt H.G. 1994. The role of copepods in the planktonic

642 ecosystems of mixed and stratified waters of the European shelf seas. Hydrobiologia

643 292/293:521-530. 


\section{Figure 1}

Map showing approximate position of the sampling stations, station P1 - Gdańsk deep and P2 - inner Gulf of Gdańsk. Gulf of Gdańsk, southern Baltic Sea in 2010-2011. (author: Anna Tarała from the Maritime Institute in Gdansk).

Author: Anna Tarała from the Maritime Institute in Gdansk. 


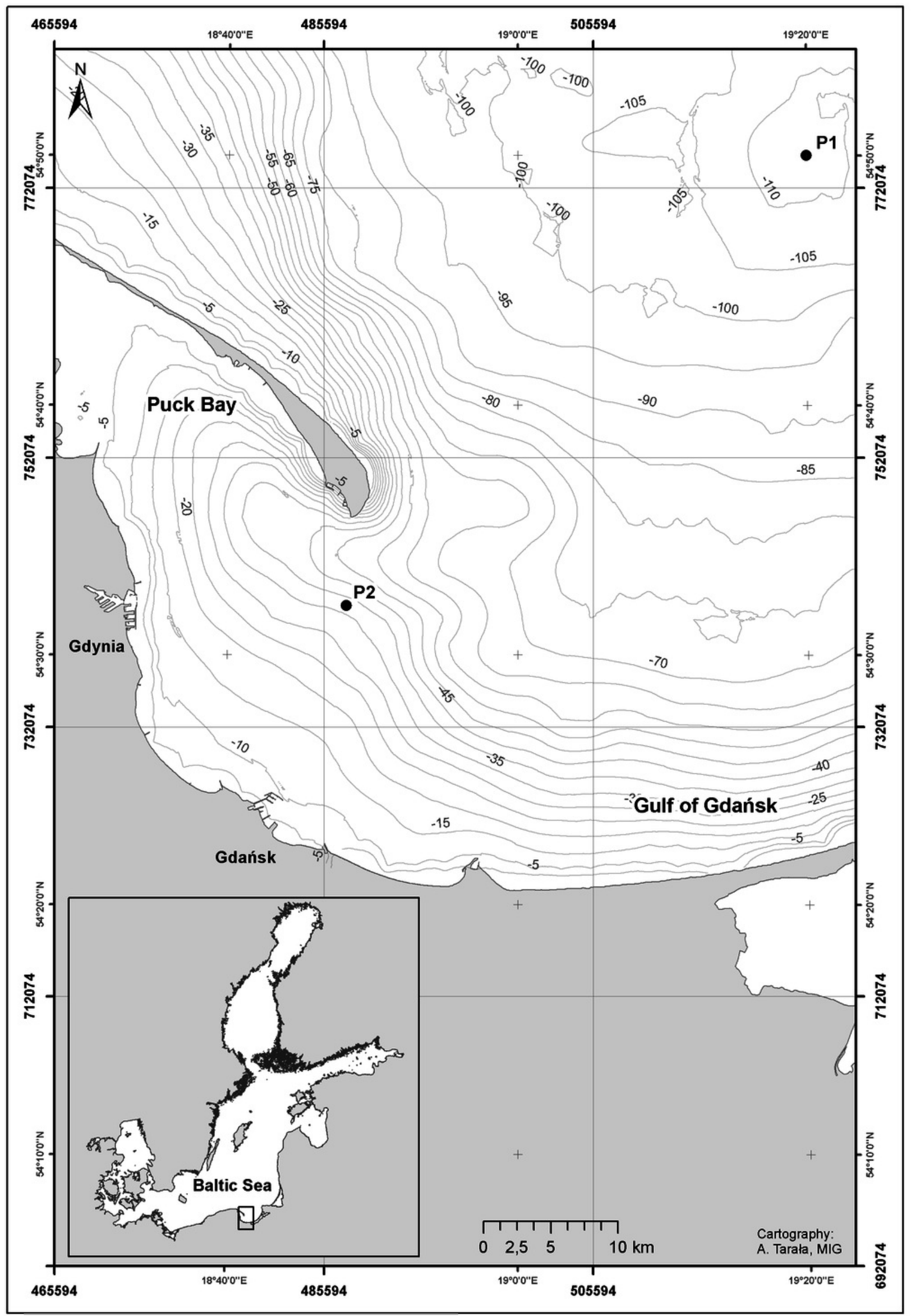

Peer] reviewing PDF | (2018:02:25101:2:0:NEW 21 Jul 2018) 
Figure 2

Abundance of Copepoda, data integrated for the whole water column at station P1 (Gdańsk Deep) in 2010-2011.

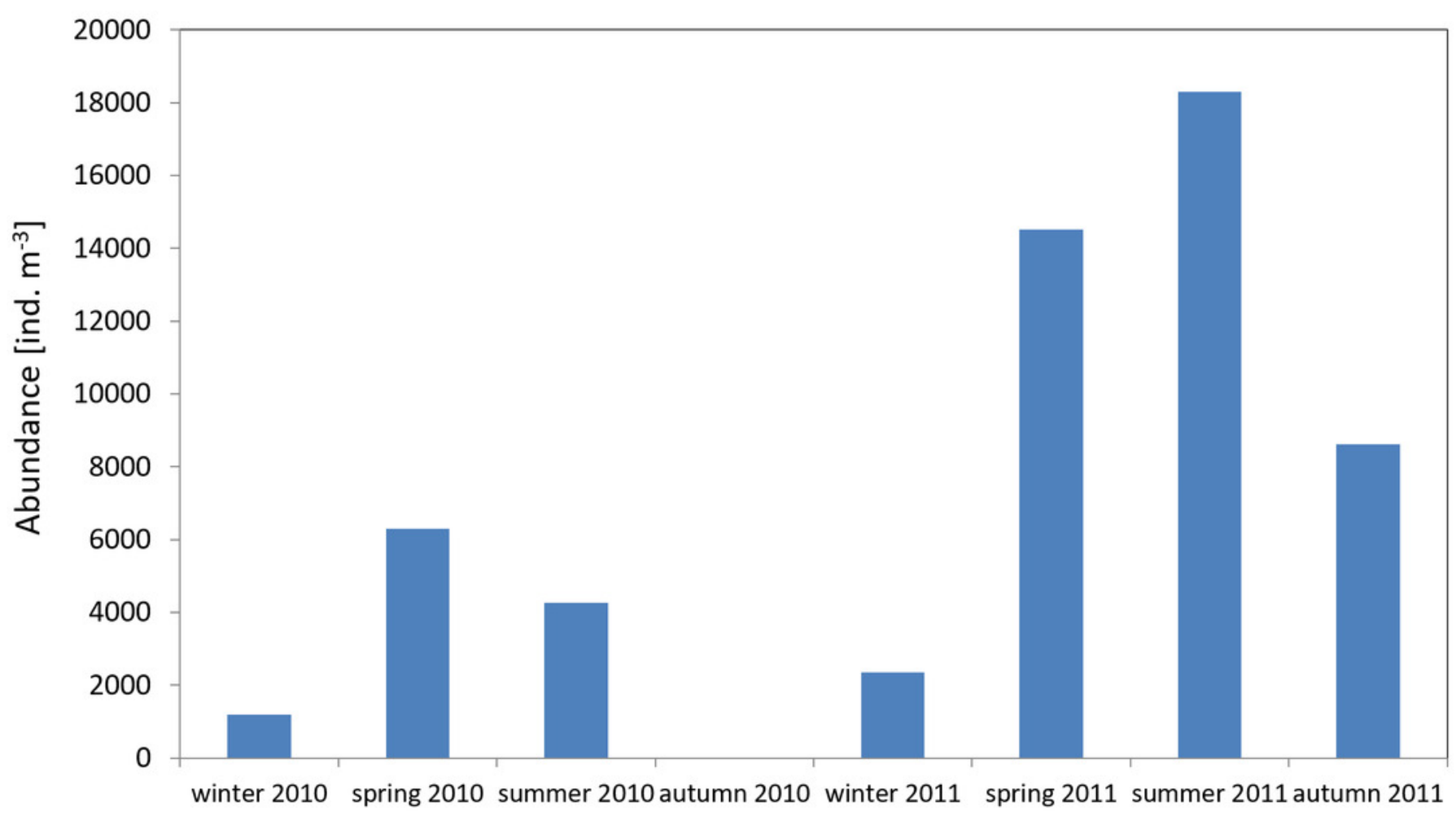


Figure 3

Taxonomic structure of Copepoda abundance at station P1 (Gdańsk Deep, data integrated for the whole water column) in 2010-2011.

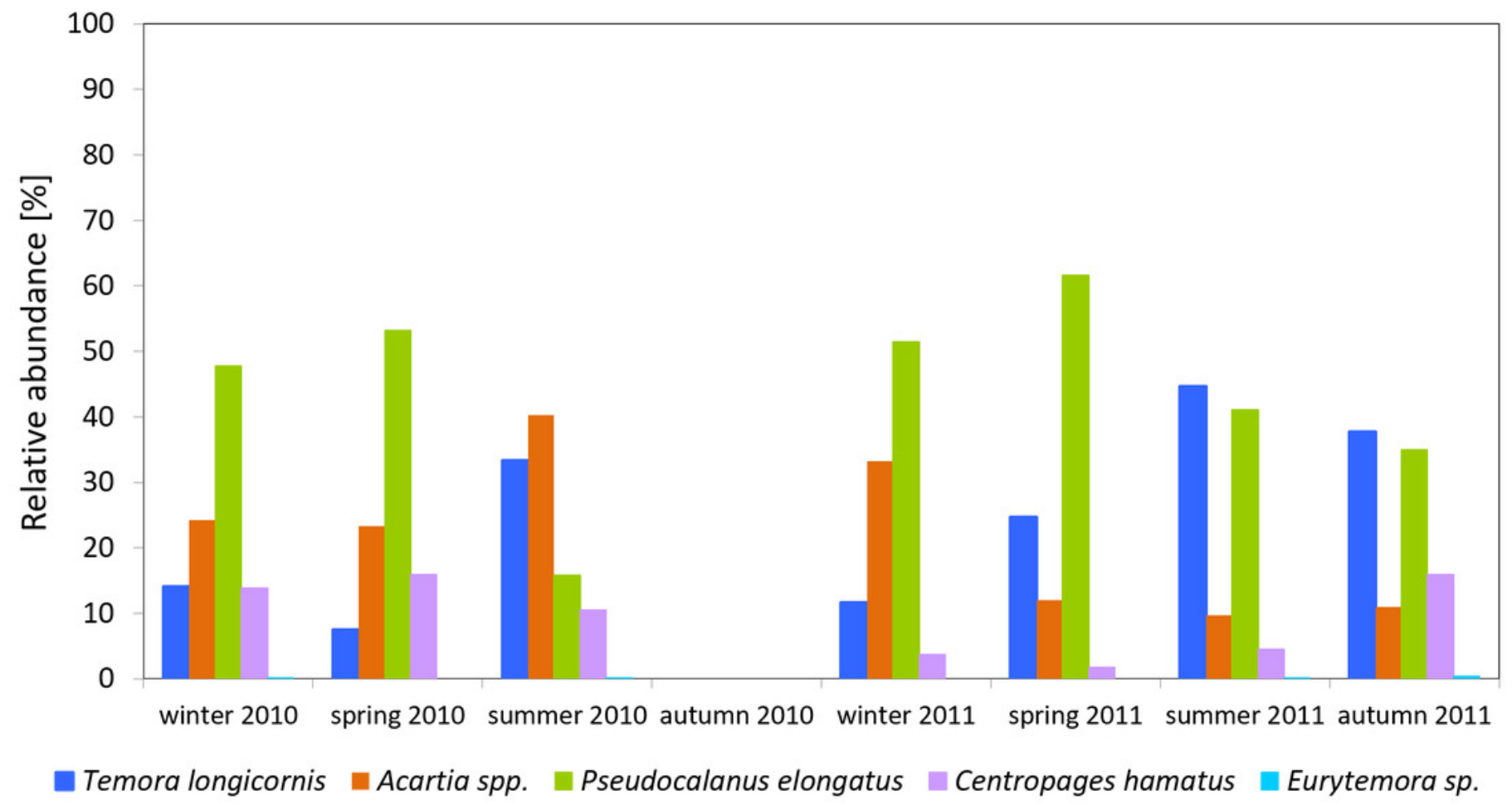


Figure 4

Taxonomic structure of Copepoda abundance at station P2 (inner Gulf of Gdańsk, data integrated for the whole water column) in 2010.

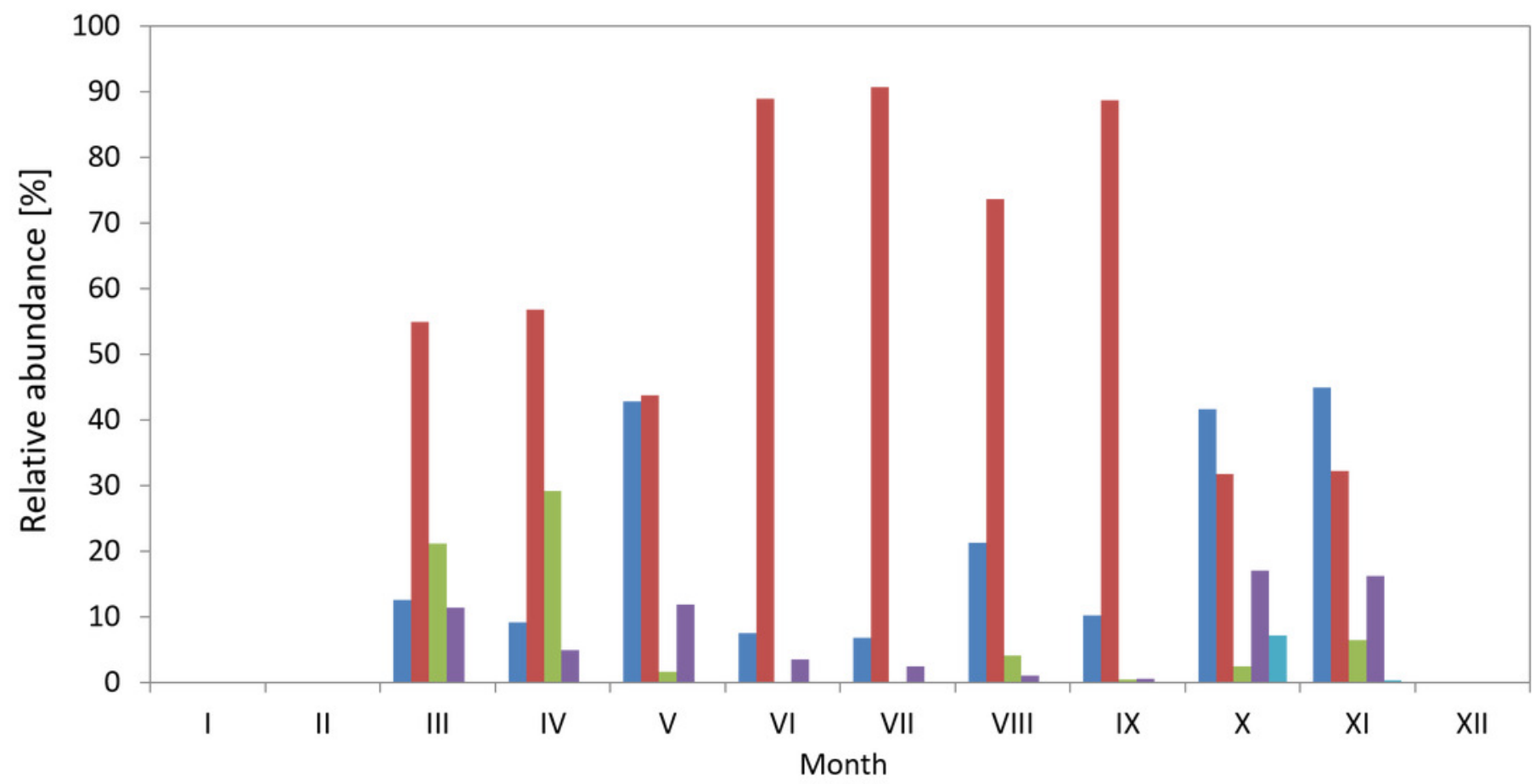

- Temora longicornis $\square$ Acartia spp. $\quad$ Pseudocalanus elongatus $\square$ Centropages hamatus $\square$ Eurytemora sp. 
Figure 5

Taxonomic structure of Copepoda abundance at station P2 (inner Gulf of Gdansk, data integrated for the whole water column) in 2011.

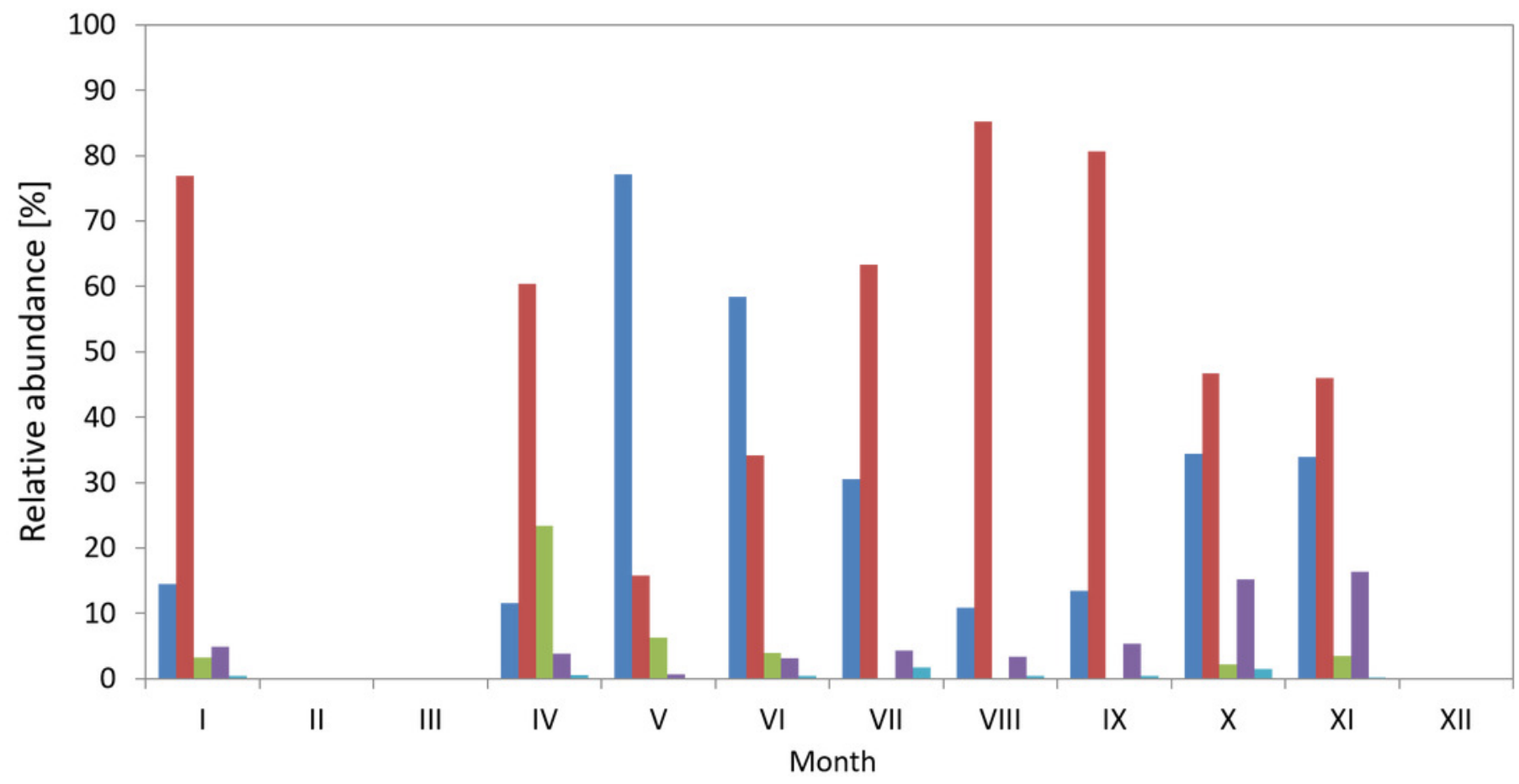

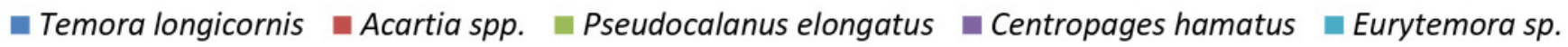


Figure 6

Abundance of Copepoda, data integrated for the whole water column at station P2 (inner Gulf of Gdańsk) in 2010-2011.

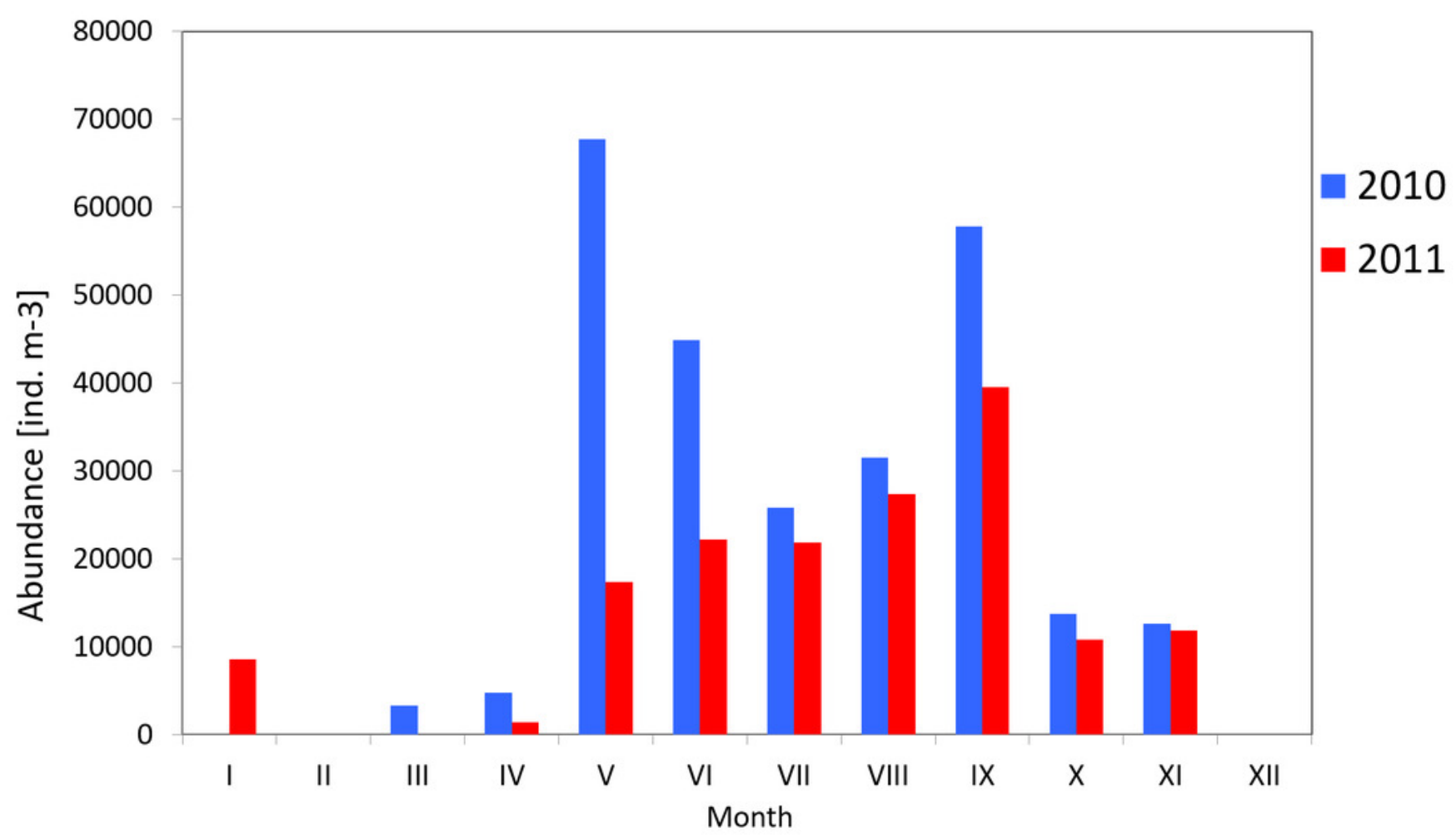


Figure 7

Biomass of Copepoda, data integrated for the whole water column at station P1 (Gdańsk Deep) in 2010-2011.

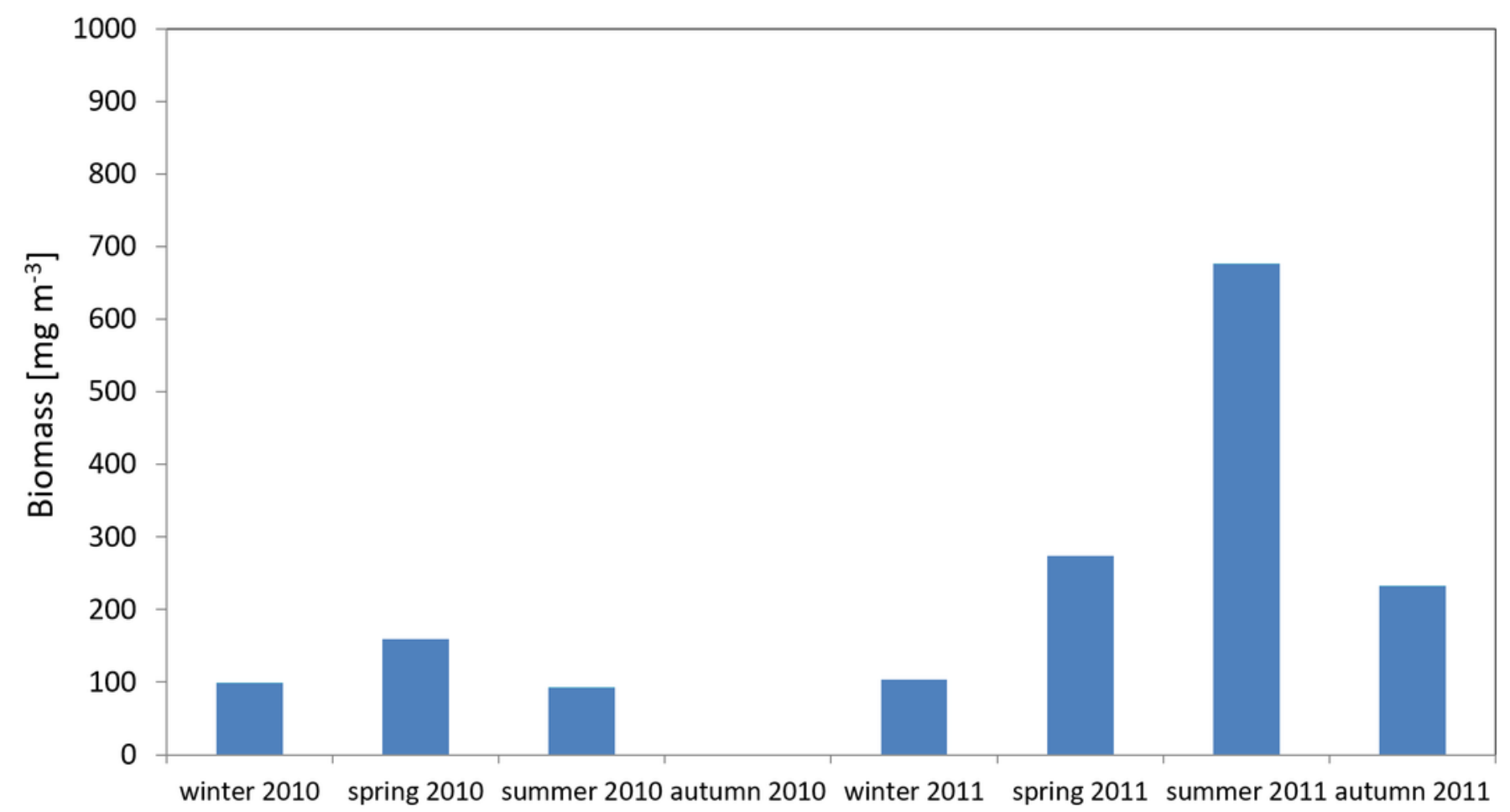


Figure 8

Taxonomic structure of Copepoda biomass at station P1 (Gdańsk Deep, data integrated for the whole water column) in 2010-2011.

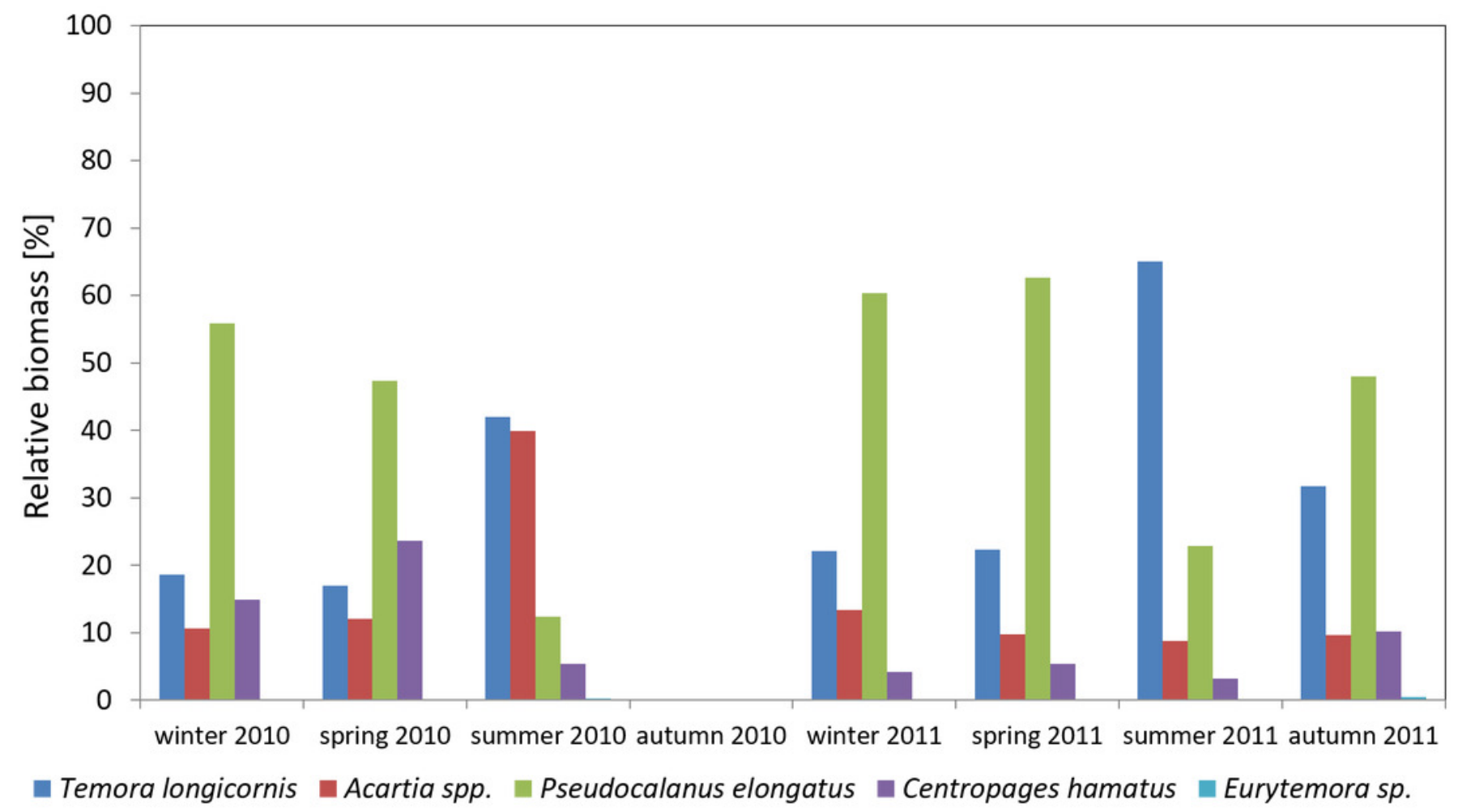


Figure 9

Biomass of Copepoda, data integrated for the whole water column at station P2 (inner Gulf of Gdańsk) in 2010-2011.

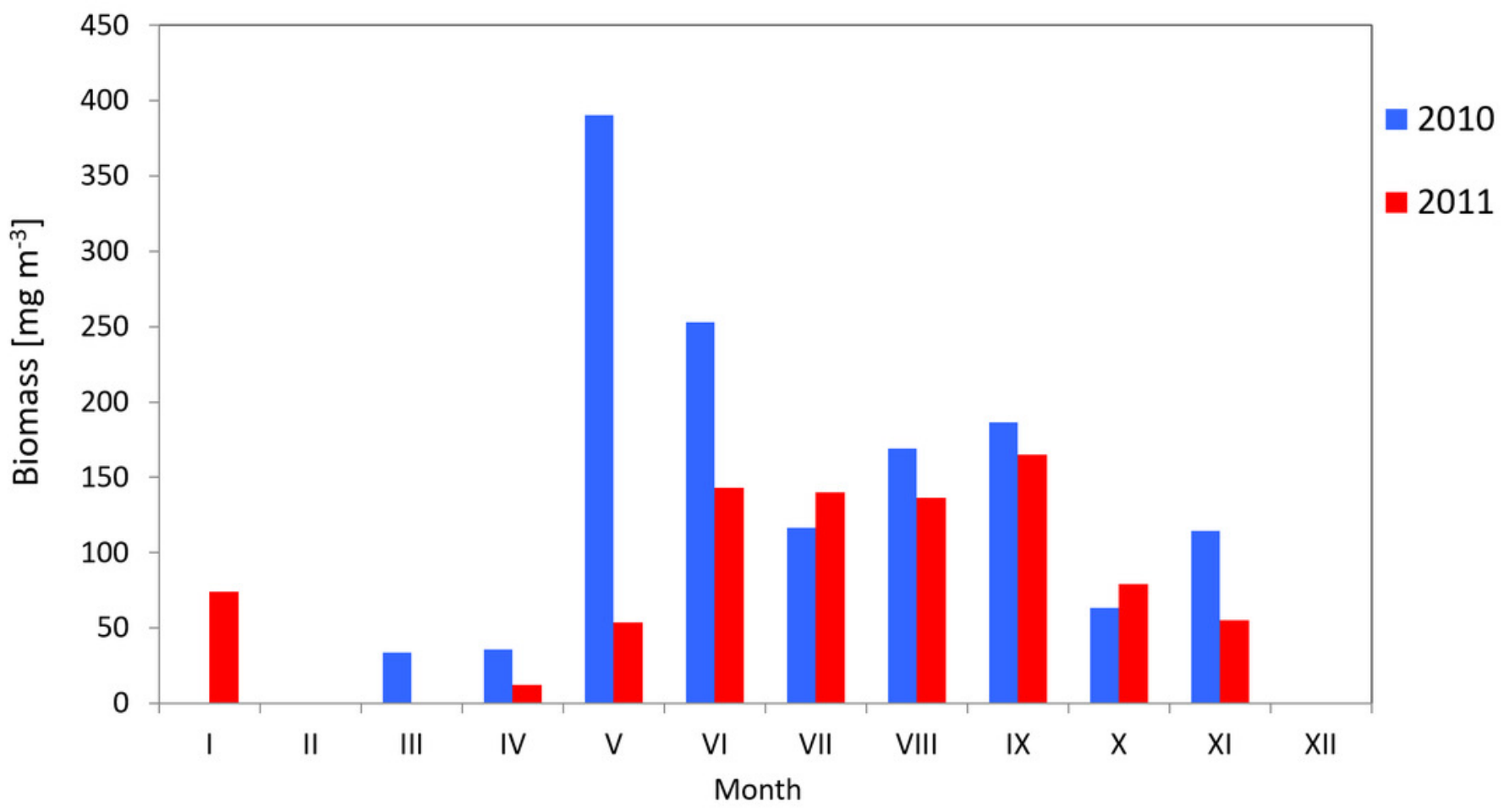


Figure 10

Taxonomic structure of Copepoda biomass at station P2 (inner Gulf of Gdańsk, data integrated for the whole water column) in 2010.

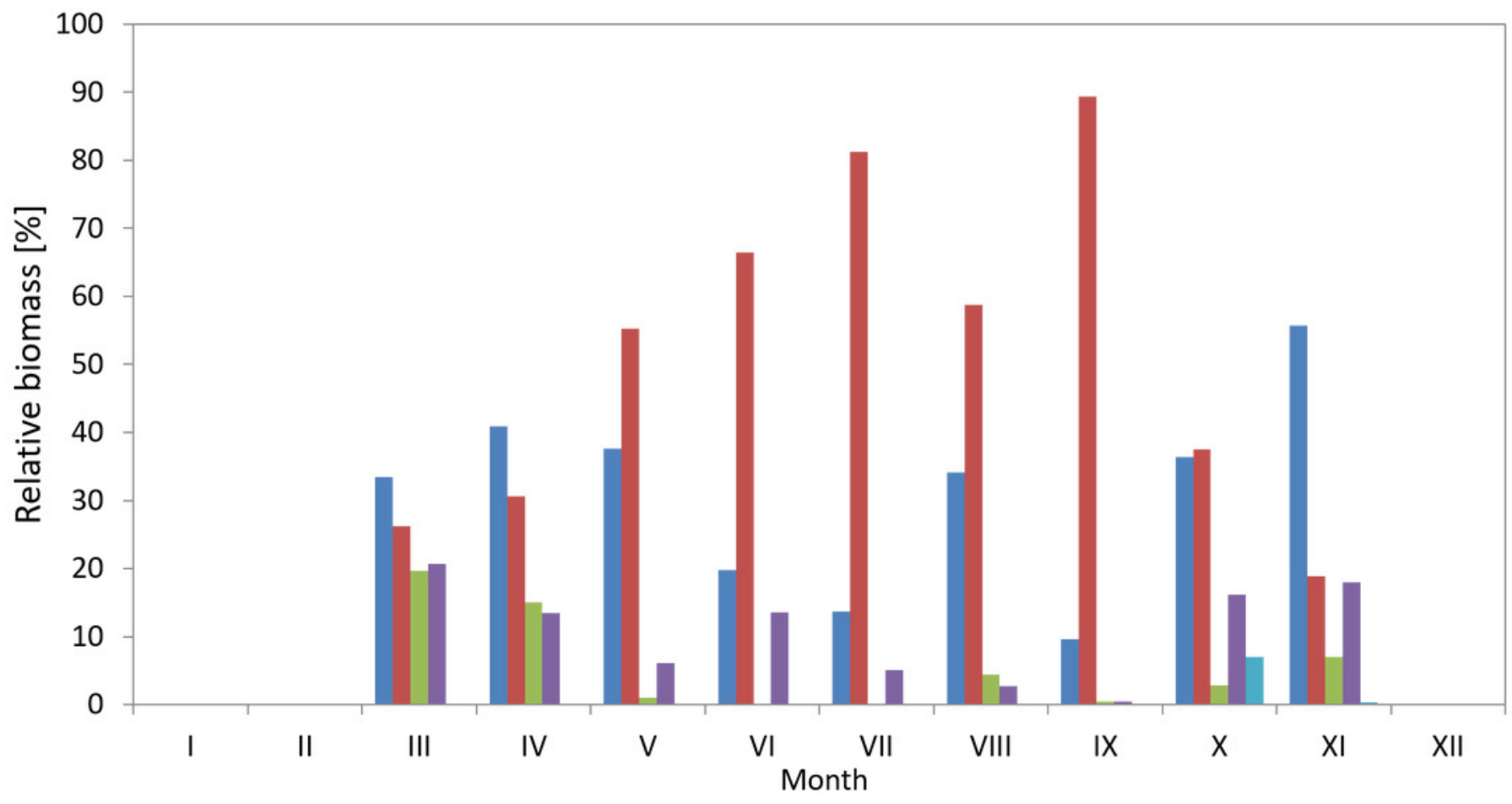

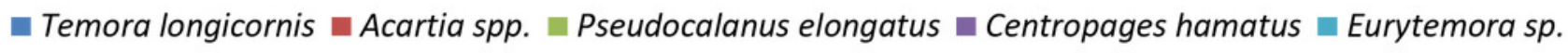


Figure 11

Taxonomic structure of Copepoda biomass at station P2 (inner Gulf of Gdańsk, data integrated for the whole water column) in 2011.

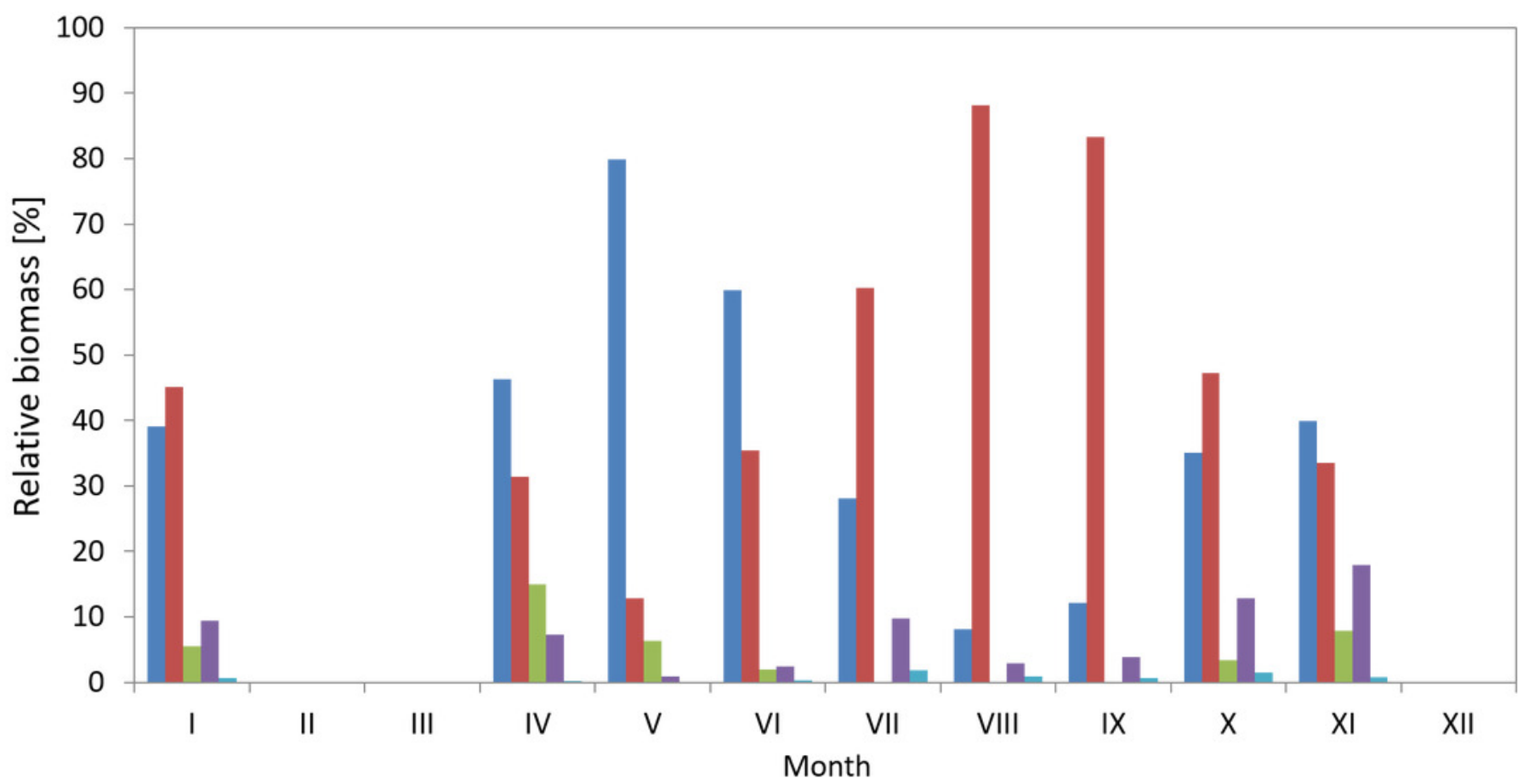

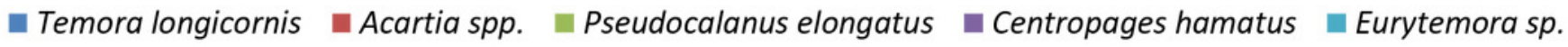




\section{Figure 12}

Abundance of zooplankton, data integrated for the whole water column at station P1 (inner Gulf of Gdańsk) in 2010-2011.

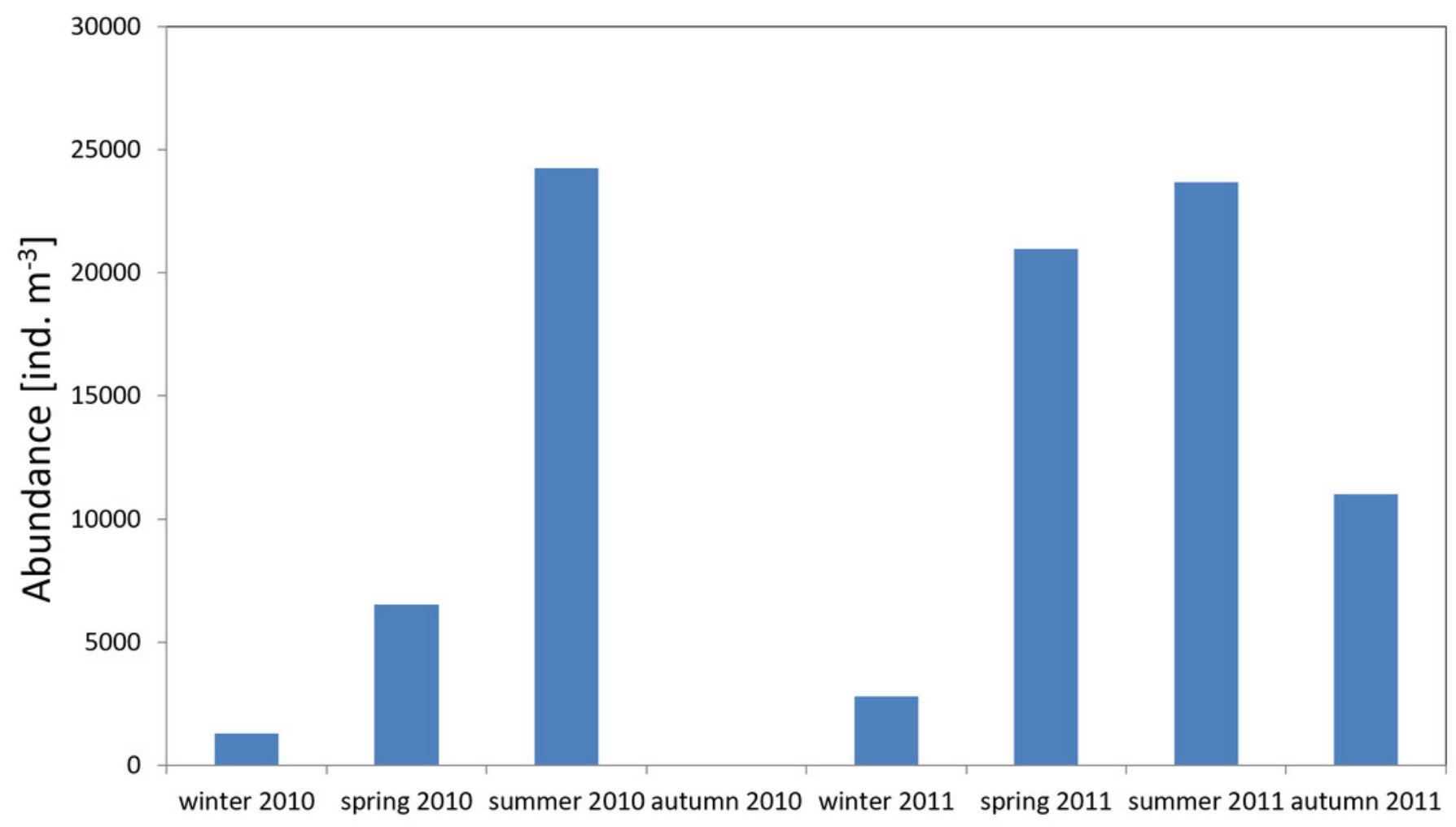




\section{Figure 13}

Abundance of zooplankton, data integrated for the whole water column at station P2 (Gdańsk Deep) in 2010-2011.

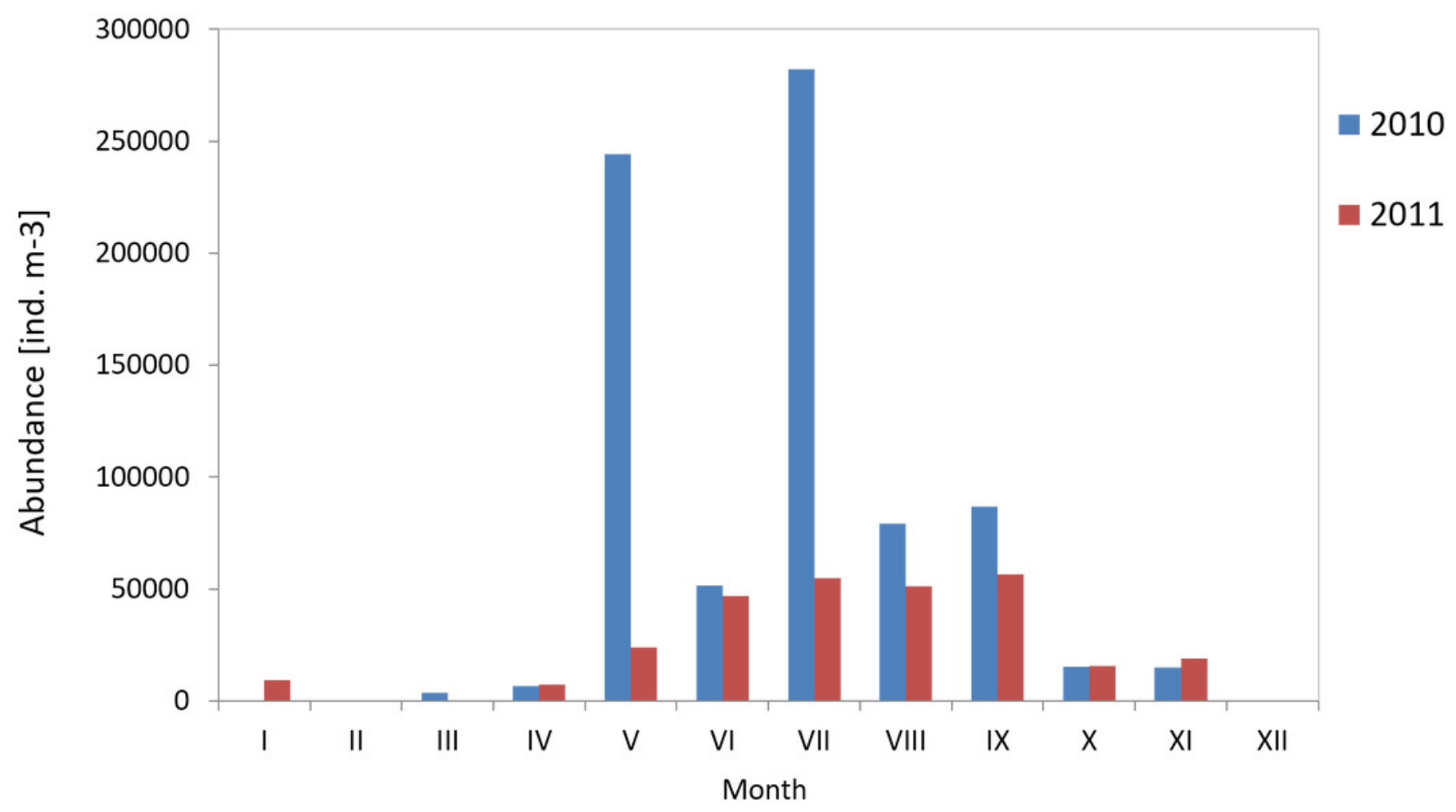




\section{Table $\mathbf{1}$ (on next page)}

Abundance (ind. $\mathrm{m}^{-3}$ ) - max (left column) and mean (right column) of Acartia spp., Temora longicornis, Pseudocalanus sp. at station P2 in the inner Gulf of Gdańsk and at stations B1-B4 and B5-B9 in Lithuanian waters.

Data from the inner Gulf of Gdańsk for 2006 and 2007 (Dzierzbicka-Głowacka, Kalarus \& Żmijewska, 2013), 2010 and 2011 (S2, S3, S4, S5 Data). Data from Lithuanian waters coastal stations (B1-B4)* and open sea stations (B5-B9)** for 2014 - Evelina Grinienè, unpublished data. 
1

\begin{tabular}{|c|c|c|}
\hline year & $\max$ ind. $\mathrm{m}^{-3}$ (month and layer) & average ind. $\mathrm{m}^{-3}$ (month) \\
\hline 2006 & 57500 (July in 40-30 m ) & 25600 (June) \\
\hline 2007 & 127000 (July in $20-10 \mathrm{~m}$ ) & 83500 (July) \\
\hline 2010 & 161150 (May in 10-0 m) & 67790 (May) \\
\hline 2011 & 70300 (Sept. in $10-0 \mathrm{~m}$ ) & 39560 (Sept.) \\
\hline $2014^{*}$ & 40317 (July in 25-0 m) & 36320 (July) \\
\hline $2014^{* *}$ & 43912 (July in 25-0 m) & 21327 (July) \\
\hline
\end{tabular}

2 


\section{Table 2 (on next page)}

Maximum contribution (in \%) of Acartia spp., Temora longicornis and Pseudocalanus sp. to the total abundance of Copepoda at stations P1 and P2 in the Gulf of Gdańsk and at stations B1-B4 and B5-B9 in Lithuanian waters.

Data from the inner Gulf of Gdańsk for 2006 and 2007 (Dzierzbicka-Głowacka, Kalarus \& Żmijewska, 2013), 2010 and 2011 (S2, S3, S4, S5 Data). Data from Lithuanian waters coastal stations (B1-B4)* and open sea stations (B5-B9)** for 2014 - Evelina Grinienè, unpublished data. [ ] - Max \% in separate station from stations B1-B4 and B5-B9; ( ) - Averaged per stations B1-B4 and B5-B9. 
1

2

3

\begin{tabular}{lccc}
\hline & Acartia spp. & Temora longicornis & Pseudocalanus sp. \\
\hline $2006(\mathrm{P} 2)$ & 86 (Sept.) & 57 (Nov.) & 25 (Feb.) \\
2007 (P2) & 82 (Aug. and Sept.) & 51 (June) & 25 (March) \\
2010 (P2) & 90 (June, July and Sept.) & 45 (Nov.) & 29 (April) \\
$2011(\mathrm{P} 2)$ & 85 (Aug.) & 77 (May) & 23 (April) \\
$2010(\mathrm{P} 1)$ & 40 (June) & 33 (June) & 53 (April) \\
$2011(\mathrm{P} 1)$ & 33 (March) & 45 (June) & 62 (May) \\
$2014^{*}$ & {$[57](43)$ (July) } & {$[66](47)$ (July) } & {$[39](13)$ (April) } \\
$2014^{* *}$ & {$[59]$ (39) (April) } & [71] (56) (July) & {$[69]$ (37) (April) } \\
\hline
\end{tabular}

4 